\title{
Do Foreign Firms Really Pay Higher Wages? Evidence from Different Estimators
}

\author{
Pedro S. Martins ${ }^{\#}$ \\ Queen Mary, University of London
}

\author{
23 September 2004
}

\begin{abstract}
:
We contribute to the literature on Foreign Direct Investment and labour markets by examining wage differentials between domestic and foreign firms, drawing on a large Portuguese matched employer-employee panel. Using OLS, the foreign-firm premium is large and significantly positive but falls substantially when firm and worker controls are added. Moreover, the premium also does not vary monotonically with foreign control, increases along the wage distribution and is generally insignificant when using propensity score matching (PSM). Finally, using differences-in-differences (DID), we find lower wage growth for workers in domestic firms that are acquired by foreign investors, a result that holds when combining DID and PSM. Overall, our evidence suggests that the commonly-documented OLS premium cannot be interpreted as a causal impact.
\end{abstract}

JEL codes: C23, F23, J31.

Keywords: FDI, Wages, Matched Employer-Employee Data, Propensity Score Matching, Portugal.

\footnotetext{
* I thank Arnaud Chevalier, José Ferreira Machado, Sourafel Girma, Diogo Lucena, Robin Naylor, Pedro Portugal, Ian Walker and conference/seminar participants at HWWA (Hamburg), GEP (Nottingham), Banco de Portugal (Lisbon), EEA (Madrid), EALE (Lisbon) and the London School of Economics for useful comments and suggestions. Financial support from Fundação para a Ciência e a Tecnologia (POCTI/ECO/33089/99, SFRH/BD/934/2000) and logistical support from Banco de Portugal and ETLA (Helsinki) are gratefully acknowledged. The standard disclaimer applies.

\# Email: p.martins@qmul.ac.uk. Web: www.qmul.ac.uk/ bsw019. Address: Centre for Business Management, Queen Mary, University of London, Mile End Road, London E1 4NS, UK. Phone: +44 (0) 2078827472. Fax: +44 (0) 2078823615.
} 


\section{Introduction}

Globalisation, or increasing international economic integration, is arguably one of the main forces that have shaped the world since the second half of the $20^{\text {th }}$ century. The increasing ubiquity of the many symptoms of globalisation, in particular the large trade, investment and worker flows, has therefore led to substantial interest in the economic impacts of these changes. As the economic domain that plays the greater direct role in the determination of people's welfare, the labour market has received considerable attention by economists interested in evaluating the consequences of globalisation.

One specific aspect of this topic that has sparked considerable controversy is the impact of foreign firms on wages. On the one hand, many individuals and organisations, mostly outside academia, claim that multinational firms pay lower wages, especially in developing countries, and present that perception as a key motivation for their opposition to globalisation. However, on the other hand, this topic boasts a clear stylised fact within academic circles, which argue precisely the opposite of what is asserted by the opponents to globalisation: as discussed below, an overwhelming majority of studies finds that foreign-owned firms pay higher wages, to equivalent workers, than their domestic-owned counterparts.

This is a debate of great importance also for policy-makers across the world, who have in many cases invested large amounts of public funds in order to attract foreign multinationals to their economies, possibly believing that the presence of these firms could be an important source of increased prosperity. One channel of such presumed impacts includes the employment created by such foreign-owned firms and the higher wages they are perceived to pay, at least when one takes into account most of the available academic research. ${ }^{1}$ In this context, it is also important to make sure that foreign direct investment does indeed lead to the creation of high-wage firms.

A final motivation point concerns the debate about the relative importance of international trade and technology in explaining the increasing wage inequality observed in some countries, in particular the U.S. and the U.K., since the 1980's (Feenstra and Hanson, 1999). Regardless of whether one considers FDI by itself or as component of trade, it is also of interest from the point

\footnotetext{
${ }^{1}$ Another channel concerns the possible (productivity) spillovers to domestic firms. In this case, recent literature surveys (see Görg and Greenaway, 2004) find, at best, mixed effects.
} 
of view of this literature to assess whether increasing FDI flows can explain higher wage inequality in host countries. Of course, this will be the case if similar workers are paid different wage rates depending on the nationality of their firms, which is consistent with the observed increase of within or residual inequality.

In this context, this paper aims at examining the robustness of the wage premium attributed to foreign firms. In particular, we try to assess whether that premium can be understood in terms of a causal impact of the firms' ownership type (domestic or foreign) on wages. This causal impact is, in our view, the parameter of interest should one want to understand the consequences of this aspect of globalisation (its link with wages), rather than simply to describe a statistical result.

Our methodology involves studying differences in pay between workers in foreign and domestic firms using different econometric methods, each of them drawing on different assumptions and focusing on different aspects of the wage determination process. Such variety of methods is facilitated by our use of a large matched employer-employee panel data set, covering more than five million workers-year in the Portuguese labour market over the 1991-99 period. Portugal is also an interesting case study, as it has received large inflows of Foreign Direct Investment since European Union membership in 1986. Moreover, wages in Portugal have been the lowest in the European Union up to the 2004 enlargement: this may possibly make it easier to observe higher wages in foreign firms.

As to our results, when using standard (OLS) methods we find that foreign firms (defined in different ways) pay higher wages. However, this result does not hold with different econometric methods. For instance, we do not observe a higher wage premium for firms that exhibit a stronger degree of control by foreign parties. More importantly, the result of a significantly positive wage premium is not obtained when workers in domestic and foreign firms are matched by their propensity scores. The same occurs when we look at the same set of workers before and after their initially-domestic-owned firms are acquired by foreign investors and compare that with workers whose firms remain domestically owned. Overall, we conclude that our results indicate that there is not a causal effect of foreign ownership on wages.

The structure of the paper is as follows. Section 2 briefly surveys some of the key contributions in the literature on the foreign-firm wage premium and critically evaluates their possible 
theoretical underpinnings. Section 3 presents the data set used and some descriptive statistics. Section 4 presents the results, obtained under different estimators. Finally, Section 5 concludes.

\section{Literature and Theory}

As mentioned in the introduction, the empirical literature that examines the impact of foreign firms on host-country labour markets typically finds that such firms pay higher wages. Below we briefly summarise some of the main contributions.

In an important study, Aitken et al. (1996) use establishment level cross-sections for Mexico, the USA and Venezuela and find evidence of higher wages in foreign firms in the three countries covered. Using OLS, the premium ranges between 38\% in Mexico and 12\% in the US, across different specifications. Feliciano and Lipsey (1999) focus on the US case using industry-stateownership cells and again find evidence of a positive wage differential, but which however disappears (for the manufacturing sector only) when controls for firm characteristics are added. Griffith and Simpson (2003) present estimates for the UK, finding in all specifications positive premia for foreign firms.

In research that focuses only on developing countries, Lipsey and Sjoholm (2001) study the Indonesian case and find a premium of $12 \%$ for blue-collar workers and $22 \%$ for white-collar workers. The results are obtained by drawing on a 1996 cross-section of plants and regressing average wages on plant characteristics, including their domestic or foreign ownership type. Velde and Morrissey (2003) examine the cases of five African countries (Cameroon, Ghana, Kenya, Zambia and Zimbabwe) and again find that foreign firms pay higher wages (the premia range between $8 \%$ and $23 \%$ across the counries). Similar results are documented for Ghana by Görg et al. (2002). ${ }^{2}$

From this brief literature survey, one concludes that there is a great degree of agreement in the empirical research about the wage practices of foreign firms in host labour markets: foreign

\footnotetext{
${ }^{2}$ Another strand in this literature adopts a difference-in-differences approach at the wage differences following the acquisition of domestic firms by foreign investors. These studies, which also generally conclude that wages increase in firms that undergo acquisition, are examined in Section 4.5. A different strand, not directly related to our topic in
} 
firms pay higher wages to equivalent workers. One also notices that most papers draw on similar research methodologies, namely by applying OLS to firm-level data. However, it is well known that a causal interpretation of these findings under OLS requires the (strong) assumption of orthogonality of firm ownership with respect to the error term. Moreover, domestic and foreign firms typically display very different (observable) characteristics. For instance, it is not uncommon that the average size (number of workers) of foreign firms is at least five times that of the size of domestic firms. To this extent, given the different supports for each type of firms, the quality of like-for-like comparisons produced by OLS may be poor, leading to biased results. These hypotheses (about orthogonality and the quality of comparisons) are explored in greater detail in Section 4.

Before that, we present and critically evaluate some theoretical views that have been put forward to explain the stylised fact that foreign firms pay higher wages. From our reading of the literature, we consider the following four possible views: increased labour demand, rent sharing, compensating differentials, and unobservable heterogeneity.

The first explanation is that foreign firms, as they enter the domestic country, may increase labour demand. This will necessarily occur in the case of greenfield investments. It may also possibly occur in the case of acquisitions - the most predominant method of entry for foreign firms in developed countries - if, for instance, (foreign) multinationals ${ }^{3}$ decide to expand production in the host country beyond the previous output level of the acquired firm and that implies hiring additional workers. Moreover, should the labour supply curve be positively sloped, then wages for the marginal workers hired by multinationals will be higher than those of infra-marginal workers.

One concern with this and other similar views is that the nationality of the firm per se would not be expected to matter, in the sense of being a key determinant in the increase of labour demand: the same increase would also apply to domestic firms that entered the market or increased their workforce. Moreover, it is important to stress that the higher wages paid by foreign firms would critically depend on the labour market not being sufficiently competitive. Otherwise, the wage

this paper, looks at wage spillovers from foreign to domestic firms: see Aitken et al (1996) and Feenstra and Hanson (1997).

3 Throughout the text we use "foreign firms" and "multinationals" interchangeably: Portuguese firms with subsidiaries abroad are considered as domestic firms for the purposes of this paper. 
differentials would not be sustained for long as the rents of workers in (new and/or expanding) foreign firms would be competed away via worker mobility from domestic firms. If, on the other hand, labour markets are competitive, such wage differentials would probably not even arise in the first instance, as labour supply curves under competitive markets would be essentially horizontal: this is precisely the standard view in neoclassical trade theory.

At this stage, we should underline that a competitive labour market model is unlikely to apply in the case of many countries. This is particularly true for Portugal, the country studied in this paper, given the rigidities brought by institutions (namely labour law) and other non-competitive forces. ${ }^{4}$ In this context, our choice of Portugal as the country under study biases our analysis against the rejection of the hypothesis of a foreign-firm premium, at least under the labour demand explanation. In other words, since the labour market presents many non-competitive features, it is more likely that higher wages in foreign firms will not be competed away by workers in domestic firms and that new or expanding firms will face a positively sloped labour supply curve.

A second explanation is that multinationals may pay a wage premium to dissuade workers from moving to other firms or disrupting activity. This is consistent with the Ownership-LocationInternalisation model of Dunning (1977), in particular with the internalisation motive. ${ }^{5}$ Under this model, foreign firms own special assets (e.g. new products or technologies) that are more profitably exploited abroad via FDI than via exporting (or franchising schemes). Foreign firms would then pay higher wages in order to prevent the costly turnover which would occur once quitters provided insights about the multinationals' specific assets to competing firms (see Fosfuri et al., 2001). Alternatively, or complementarily, foreign firms may share with workers some of the rents produced by those assets, driving their wages above those of comparable individuals working in firms that do not generate such rents.

\footnotetext{
${ }^{4}$ For instance, Blanchard and Portugal (2001) highlight the large burden to economic efficiency brought by restrictive firing regulations. Portugal and Cardoso (2003) also do not find any employment effects of minimum wage laws, unlike what one expects in a competitive market. Additionally, Martins (2004c) presents evidence of substantial levels of rent sharing.

${ }^{5}$ Other prominent models of FDI, such as the vertical, horizontal and capital-knowledge models, are more difficult to be applied in the context of pay determination. But see Markusen and Venables (1997) for a study of the role of multinationals in explaining wage inequality (between skilled and unskilled workers) and Martins (2004b) for an examination of different FDI models using US domestic and multinational data.
} 
Although this type of explanation is appealing, it again raises some concerns. One issue is that, while foreign firms may indeed generate rents, such firms are also likely to have stronger bargaining power than domestic firms, since they may easily shift production (and thus employment) across countries (see Caves, 1996, pp. 123-131). Consistent results are obtained in Martins (2003b), which compares the extent of rent sharing in large, export-oriented domesticand foreign-owned firms in Portugal and rejects the hypothesis that workers in foreign firms benefit more from rent sharing than similar workers in domestic firms.

Another concern is that this rent-sharing view assumes that foreign firms are more likely to draw on special assets than a representative domestic firm. In other words, it may not be "foreignness" itself that drives the pay gap, but rather the differences in the average characteristics of domestic and foreign firms. In this case, one again cannot interpret the pay differences between the two types of firms in a causal way.

A third explanation for the stylised fact that foreign firms pay higher wages is about compensating differentials. For instance, multinationals may provide less interesting job amenities than domestic firms. Workers would thus have to be compensated in the form of higher wages in order to take jobs in foreign-owned firms. Although this view is theoretically reasonable, it would mean that workers are not better-off in foreign-owned firms. Moreover, the little evidence available, including Sutherland (2002) and Brown et al (2003) for developed and developing countries, respectively, suggests that working conditions are better in foreign firms. The first paper finds that workers exhibit higher levels of job satisfaction in foreign-owned firms while the second suggests that working conditions are more enjoyable in foreign firms. In their study of Portugal, Mata and Portugal (2002) also find no differences in exit probabilities between domestic and foreign firms: workers would therefore be expected not to demand a pay premium to compensate them for a higher probability of displacement when employed by a foreign firm. ${ }^{6}$

Finally, foreign firms may select workers that are more skilled in dimensions unobservable to the researcher. For instance, given the larger size of multinationals, both when taken individually in each host country and particularly when taken jointly in all countries in which

\footnotetext{
${ }^{6}$ Görg and Strobl (2003) find mixed results for the case of Ireland: foreign firms are more likely to exit but the jobs they create are more persistent.
} 
they operate, these firms may benefit from scale economies in setting up sophisticated human resource departments. This would allow these firms to screen and hire the best applicants for their vacancies, possibly also along dimensions of skill not observable by the researcher. Under this case, the wage differential attributed to multinationals would be spurious and no causal impact of foreign ownership upon wages could be inferred. This also means that evidence of wage differentials should not necessarily support the case for government intervention, to the extent that foreign firms are not effectively paying higher wages to comparable workers.

Overall, we conclude in this section that there are few, if any, theoretical reasons to reconcile the empirical stylised fact of a foreign-firm wage premium with a causal relationship between foreign ownership and pay. Moreover, the little empirical evidence available does not support such theoretical explanations. The strongest account is probably that labour markets may not be sufficiently competitive, but even this view does not highlight any reasons why foreign firms would be different from similar domestic firms. This conclusion further motivates the empirical work carried out in this paper, in which we empirically examine the robustness of the stylised fact about pay differences between foreign and domestic firms.

\section{Data}

Our analysis draws on a large matched employer-employee data set, "Quadros de Pessoal" (Personnel Records). This is a compulsory survey run by the Ministry of Employment and which covers all firms located in Portugal with at least one employee. Those firms are required to provide information on an annual basis about their characteristics and those of their workforce. The former variables include geographical location, industry, sales and the share of the firm's equity owned by foreign parties. The set of worker characteristics includes gender, highest qualification, tenure, wages and hours worked.

There are also unique (time-invariant) identifiers for each firm and each worker that allow each one of them to be followed over time. Information for each worker-year also includes his/her employer's identifier, allowing for the matching of the two sides of the labour market. It should also be mentioned that particular care is placed on the reliability of the information, as that is 
used by the Ministry of Employment for the purpose of checking the employer's compliance with labour law.

The data set considered here is an $80 \%$ representative sample of all manufacturing sector firms. The information refers to each year in the period 1991-99 and to a specific month of each year (March up to 1993 and October from 1994 onwards). There is also information on all workers of each firm sampled in each year. ${ }^{7}$ This amounts to an annual average of about 678,000 workers per year and 29,481 firms (and a total of 71,240 different firms). After dropping observations with missing or inconsistent information in key variables and firms based outside continental Portugal we obtain a data set with an annual average of 601,000 workers and 16,935 firms (and a total of 39,783 different firms).

The foreign/domestic firm ownership type is derived from the share of equity held by foreign nationals. We define as foreign firms those for which at least $50 \%$ of equity is owned by foreign parties, ${ }^{8}$ and we obtain an annual average of 16,557 domestic and 378 foreign firms. These firms correspond to 434,000 workers in domestic firms and 62,600 workers in foreign firms - the yearly data are available on Tables 1 (workers) and 2 (firms). This sizeable share of workers in foreign firms is also in line with the large flows of inward FDI in Portugal, especially since European Union membership in 1986 - over the 1990's, such flows averaged about 7\% of GDP per year.

The descriptive statistics reveal some important differences between foreign and domestic firms. For instance, in all measures of earnings (monthly or hourly), workers in foreign firms earn more than their counterparts in domestic firms. In 1991, for example, the average worker in a foreign firm earned €691 per month (2000 prices), whilst the average worker in a domestic firm

\footnotetext{
${ }^{7}$ This means there is attrition in the panel at the firm level but not at the worker level: only the workers of the firms that are not sampled in a given year will not be present in the data.

${ }^{8}$ Some authors use a $10 \%$ threshold, in line with the International Monetary Fund criterion that distinguishes between portfolio and direct foreign investment flows. We have opted for the $50 \%$ level instead because we want to focus on the impacts of foreign firm ownership (and not of firms with some positive level of foreign participation). However, we acknowledge that a $50 \%$ foreign-ownership share is not either a necessary or a sufficient condition for foreign control, since there may be more than one foreign or domestic investor per firm. For the benefit of robustness, we present in the Appendix an analysis of our data using the 10\% threshold - see Tables A1a and A1b. We find little differences from the results documented in the main text. There is only a small increase in the percentage of workers in foreign firms (from 13\% to 16\%), suggesting that most firms with a positive level of foreign ownership are above the $50 \%$ threshold. These results are also consistent with those of Barbosa and Louri (2002).
} 
earned only €528, implying a pay premium of $30.9 \%$. In the end of the decade, the corresponding values were $€ 863$ and $€ 628$ (and a pay premium of 37.4\%).

These differences in earnings can be partly explained by differences in schooling attainment: workers in foreign firms are found to have an (unweighted) average of 6.9 years of schooling across the nine years covered, whereas the same figure for workers in domestic firms is only 5.8. On the other hand, workers in domestic firms are found to be more experienced. This is partly due to their lower schooling, as we are measuring Mincer experience (age-experience-6).

As to the distribution of workers by industries, again there are clear differences between domestic and foreign firms. A particularly striking contrast is the over-representation of foreign firms in the Metallic and Transport industry (43\% against 19\% of workers). In an opposite direction stands the Textiles, Clothing and Leather industry (29\% of foreign workers against $38 \%$ of domestic workers) and the Wood and Cork industry (1\% against 8\%). These differences have also a geographical dimension, as workers of foreign firm are relatively more prevalent in the Lisbon region (40\% versus 23\%) and less prevalent in the North region (40\% versus 52\%). ${ }^{9}$

A complementary way to establish the contrast between domestic and foreign ownership can be pursued by looking at firm (rather than worker) unweighted averages, i.e. without weighting firm characteristics by their firm size. This exercise - see Table 2 - reveals even stronger pay differences between foreign and domestic firms. For instance, in 1999, the average multinational paid $€ 889$ to an average worker (€502 for the average domestic firm), which amounts to a pay premium of $77.1 \%$, more than twice the premium documented for same year in Table $1 .^{10}$

\section{Results}

\subsection{OLS estimator}

\footnotetext{
${ }^{9}$ See Guimarães et al. (2000) for a study of FDI agglomeration in Portugal.

${ }^{10}$ An important explanation for this difference between the worker and firm data lies on the fact that foreign firms are, on average, much bigger, at least in terms of the number of workers. Foreign firms have an average of 190 workers whereas domestic firms have an average of only 32 workers. This helps in understanding the very large pay difference as it is well known that smaller firms pay lower wages (Brown and Medoff, 1989, and Oy and Idson,
} 
In this section, different versions of the following wage equation are considered:

$$
\mathrm{y}_{\mathrm{i}}=\mathrm{X}_{\mathrm{i}}{ }^{\prime} \beta_{1}+\mathrm{F}_{\mathrm{j}(\mathrm{i})}{ }^{\prime} \beta_{2}+\beta_{3} \text { Foreign }_{\mathrm{j}(\mathrm{i})}+\varepsilon_{\mathrm{i}}
$$

$\mathrm{y}_{\mathrm{i}}$ denotes the logarithm of real hourly wages. $\mathrm{X}_{\mathrm{i}}$ denotes a set of human capital characteristics (six dummies for educational attainment, a quartic in experience, a quadratic in tenure measured in months, and a female dummy). $F_{j(i)}$ denotes a set of characteristics of the firm $\mathrm{j}$ of worker i (four regional dummies, log number of workers, a dummy for public firms and eight industry dummies ${ }^{11}$ ). Foreign $n_{\mathrm{j}(\mathrm{i})}$ is a dummy variable taking value 1 if the firm of worker $\mathrm{i}$ is a multinational and 0 otherwise. Our attention is focused on the $\beta_{3}$ coefficient. ${ }^{12} \varepsilon_{\mathrm{i}}$ is the error term.

The first version of equation (1) includes only the foreign dummy. In this case, the wage premium for workers in foreign firms is found to average $32 \%$, ranging between $27 \%$ and $37 \%$ across the different years - see the first row of Table 3. However, as suggested before, these wage differences may be attributed to different levels of human capital. Indeed, it is found that, when one controls for these variables, the (unweighted) average premium falls to 27\% (ranging between 23\% and 32\%). Finally, when firm characteristics are also considered, the premium falls further and more substantially than when human capital variables were added. The average premium is now only $11 \%$, ranging between $8 \%$ and $13 \%{ }^{13}$

Overall, these results, which are in line with those of studies for other countries, suggest that about two thirds of the average difference in pay between domestic and foreign firms are determined by the different human capital of their workers and, more importantly, by the different characteristics of foreign and domestic firms. However, at $11 \%$, the pay gap between domestic and foreign firms is still economically significant and may suggest an important effect of multinationals on wages.

1999), although it is less well known why this is so. No other major differences are found in terms of the industry or geographical distributions of domestic and foreign firms in the worker statistics table.

${ }^{11}$ A new industry code was adopted in 1995. We use the old, more-aggregated version (“CAE-Rev.1"). Given that some firms are not available in our sample in the period 1991-1994, their industry code was obtained from extrapolating from the changes observed in such codes for firms present in both periods (1991-94 and 1995-99).

12 This coefficient is discussed in terms of percentage differences in wages, after taking into account the logarithmic transformation of wages.

${ }^{13}$ As to time trends, there is some evidence, in the first and second specifications, of increasing foreign multinational wage premia between 1991 and 1995, when they peak, and declining premia from then until 1999. This pattern is however not present in the specification that includes both human capital and firm controls. 
These results assume a constant pay premium for different industries. But there are many reasons for one to expect that foreign wage differentials to depend on the industry examined. For instance, and following the theoretical discussion in Section 2, multinationals in technologyintensive industries may have to pay larger premia so to prevent the dissemination of their new methods to competitors via workers' mobility. However, in other industries, multinationals may see no need to pay above market wages. Indeed, under the case of vertical FDI (which is the case that best fits Portugal, given its relatively small domestic market), multinationals may choose a given host country precisely in order to pay lower wages.

We look at this possibility, by allowing the multinational premium to depend on the industry. Table 4 presents the results: the first eight main rows denote the average industry premia, the following row refers to the average foreign firm premium and the last eight rows present the industry-specific premium. The comparison group (dropped dummy) is the Clothing, Textiles and Leather industry, the biggest one in our data and also one of the industries that pays the lowest premia. ${ }^{14}$ In contrast, the four industries that exhibit higher average premia are Wood, Paper, Chemicals, Non-Metallic Minerals and Metallurgic sectors.

As to the differences in the multinational premium, the industries in which the premium is larger are Food, Wood, Paper and Chemicals, where the average additional premia range between $26 \%$ (Food) and 17\% (Chemicals). In the remaining industries, Clothing, Non-Metallic Minerals, Metallurgic, Metallic and Others, the average additional premia range between 8\% (NonMetallic Minerals) and 0\% (the dropped industry, Clothing).

These findings may represent some mild support for the hypothesis described above about different incentives across different industries to pay above-market wage rates. For instance, Chemicals pay higher foreign premia and are probably a good example of an industry where patents and other inputs that generate rents are prevalent. On the other hand, Clothing, which pays the lowest wages and the lowest foreign premium, may be a good example of an industry that draws on standard technical processes.

${ }^{14}$ See Martins (2003a) for a study of wage determination in this industry. 


\subsection{Different levels of control}

In this section, we test the hypothesis that a greater share of foreign ownership leads to a greater foreign premium. This would occur under the case of a causal impact of foreign ownership upon wages. We test this by allowing the wage impact of foreign firms to differ depending on the degree of control of the firm by the multinational, as implicit in the share of the firm's equity held by foreign parties.

In particular, we create different dummy variables for firms with different share of foreign control: $1 \%-9 \%, 10-19 \%, \ldots, 90 \%-99 \%$ and 100\%. Within the group of firms which are considered as foreign-owned, the most prevalent category is that of full foreign control (which accounts for $60 \%$ of workers in foreign firms) and then that of $90 \%-99 \%$ (20\% of workers). Within the group of firms that have less than $50 \%$ foreign shares, they correspond to between $.5 \%$ and $2 \%$ of the workers in domestic firms.

We find - see Table $5 \mathrm{a}$ - positive premia for all workers whose firms have some positive share of equity held by foreign parties, regardless of the size of that share. For instance, firms with a share of equity of between $1 \%$ and $9 \%$ pay their workers, on average across the decade, $12 \%$ more than similar workers in firms without any share of equity held by foreigners.

Although average premia are higher in the 50\%-100\% range than in the $1 \%-49 \%$ range, there is no clear evidence of a monotonic relationship between premia and the share of foreign ownership. This result weakens the case for a strong causal relationship between the degree of control and the wage differential. However, one must bear in mind the relatively low number of workers in firms that exhibit low but positive levels of foreign ownership. This may explain the considerable volatility in the estimates for lower levels of foreign ownership at different years.

As a further check on this link between the degree of foreign control and the wage premium, we also investigated the wage difference between domestic and foreign firms when the latter are defined at different thresholds. Here we consider ownership starting alternatively at the $10 \%$, 20\%, 30\%, 40\% and 50\% levels and compute the premium accordingly. Taking into account the hypothesis described above that greater control translates into a higher premium, we expect that the greater the ownership threshold, the higher the premium. 
Consistently with the previous findings, the results - see Table $5 b$ - indicate that there is no monotonically positive relationship between the premium and the level of control. Moreover, in most years the premium is found to fall at higher levels of control. Overall, the results presented in this sub-section are evidence against a causal link between foreign ownership and wages.

\subsection{Quantile Regression}

As suggested in Section 2, the commonly documented wage premium of foreign firms may be explained by unobservable differences between their workers and those of domestic firms. Under this view, the average wage in foreign firms could be pushed upwards by a longer right tail of the conditional wage distributions for workers in those firms. Such longer tail would represent the higher ability (and wages) of the more skilled workers hired by foreign firms.

This difference between the wage distributions of domestic and foreign firms would however not be uncovered by OLS. This method examines only the impact of regressors on the mean of the dependent variable. In this case, quantile regression (Koenker and Bassett, 1978) can be used instead, as it examines the possibility that the impact of a regressor (the foreign-firm dummy) varies along the distribution of the dependent variable (wages). ${ }^{15}$

We test this hypothesis drawing on the wage specification of equation 1 , considering the wider set of controls for firm and worker characteristics. Using quantile regression, we look at returns at the $75^{\text {th }}$ and $25^{\text {th }}$ percentiles, which proxy the top and bottom of the wage distribution, respectively. We find that the foreign-firm wage premium is generally larger at the top than at the bottom of the distribution - see Table 6. Except for 1991 and 1992, the foreign-firm premium is always statistically larger at the top of the distribution at the $1 \%$ level (using simultaneous estimation of both quantiles) and the difference is between about 2 and 3 percentage points.

\footnotetext{
15 In the context of inter-industry wage differentials, Martins (2004a) suggests that, if such differentials are explainable by workers unobserved heterogeneity, then such wage dispersion is likely to be higher at the top than at the bottom of the wage distribution. Quantile regression would then capture the over-representation of high-ability
} 
Following the theoretical discussion in Section 2, these findings are consistent with the case of unobserved worker differences driving the foreign-firm premium. Should all workers in foreign firms be of a similar unobserved quality to their counterparts in domestic firms, one would expect the wage premium to be the same along the wage distribution. However, we show here that, although the premium is positive at the bottom of the distribution, it is even higher at the top. Therefore those workers in foreign firms whose skills place them at the top of their conditional wage distributions benefit from a stronger premium with respect to their counterparts at the bottom of the distribution. This is consistent with the view that workers in foreign firms are more skilled along unobserved dimensions. However, an alternative explanation is that foreign firms reward unobserved skills more generously.

\subsection{Propensity Score Matching}

One concern with OLS estimators is that their "like-for-like" comparisons disregard the possibility of a different support (i.e. range of values of the regressors) between observations with and without some characteristic whose impact is of interest. Moreover, the distribution of characteristics over that region of common support may also be very different between the two groups, further biasing OLS results. Heckman et al (1997) suggests that these two biases (nonoverlapping support and different distributions of covariates) are more important than the bias related to selection on unobservables. The latter bias has however received much more attention, at least in the literature on programme evaluation (e.g., job training). In their words, "the simple balancing of observables goes a long way towards effective evaluation” (p. 607).

Propensity score matching (PSM) is a non-parametric method that tackles these issues directly by restricting the analysis over the region of common support (i.e. by only comparing observations that are effectively comparable) and by taking into account the distribution of the regressors across each group under study. The relevance of this method for the analysis conducted in this paper stems from the large differences documented in terms of the observable characteristics of the two types of workers. As discussed before, these differences are particularly pronounced along the educational attainment of workers, and their firm size and

workers in high-wage industries. Unlike in the present paper, no differences in premia along the distribution are found. 
industry distribution. Failure to take this into account may thus have seriously biased our previous results.

In this sub-section, we implement PSM, using the same annual data sets described before. The variables considered for the estimation of the propensity score are: six education dummies, experience, tenure, gender, log firm size, three region dummies (north, centre and Lisbon) and four industry dummies (textiles, wood, chemicals and metallic). It is this propensity score, obtained via a logit estimation, that will be used to match workers in foreign firms to those in domestic firms, in this case via the one-to-one matching procedure. ${ }^{16}$

The first nine rows of Table 7 present the results. The estimates of the foreign firm premium range between $-8.9 \%$ (1994) and 1.1\% (1998), averaging $-1.22 \%$ over the nine years studied. Most coefficients are not significant. Therefore, the average premium (and, to a lesser extent, its variability across years) stand in clear contrast with the findings in sub-section 4.1 and in the literature of a positive and "large" impact of foreign ownership on wages. However, this is not at odds with the finding in section 4.1 that a more detailed comparison of workers in domestic and foreign firms leads to substantially lower estimates of the foreign-firm wage premium and the finding in sub-section 4.2 of no monotonic relationship between foreign control and the wage differential.

\subsection{Acquisitions - difference-in-differences}

The difference-in-differences method involves contrasting the change in a variable of interest in a group of observations that have undergone some treatment with the change in the same variable in a similar group of observations but which have not undergone such treatment. The advantage of this approach is that one is able to control indirectly for variables that may influence the parameter of interest but which may not be available, provided that such variables are time-invariant and the assignment to treatment is random. Here, we apply this method for the case of domestic firms that are acquired by multinationals: such acquisition is the treatment

\footnotetext{
${ }^{16}$ Since the estimation proved very time consuming, in particular because the standard errors are obtained via bootstrapping (50 repetitions) and the data set is very large, we use a subset of the original data set in this subsection. For each year, this subset was made of a random sample of $20 \%$ of the observations for workers in domestic firms added to the full sample of workers in foreign firms.
} 
whose impacts are studied vis-à-vis the control group of domestic firms that are not acquired over the period considered.

A similar approach is used in Conyon et al (2002) and in Almeida (2003). ${ }^{17}$ The first paper uses UK firm level panel data and focuses on the productivity and wage impacts of acquisitions, contrasting the case of acquisitions originated by foreign multinationals and other domestic firms. The authors find evidence of higher wage growth when domestic firms are acquired by multinationals than when domestic firms are not acquired by any firm. However, those domestic firms that are acquired already exhibit higher levels of wage growth before acquisition than those firms that are not acquired, suggesting some role for "cherry picking”. Another interesting result is that, after controlling for productivity, the wage differential is eliminated. ${ }^{18}$ However, it is not obvious that one should control for productivity differences. If such productivity differences are due to, say, different management practices brought by the new owners, any wage differences that arise should be interpreted as a causal impact of ownership change.

Almeida (2003) also studies the wage impacts of foreign acquisition using the "Quadros de Pessoal" data set. However, some important differences in relation to what is done in this subsection are that Almeida considers both the manufacturing and non-manufacturing sector, although using data aggregated at the firm level. Moreover, foreign ownership (or acquisition) is defined at the $10 \%$ equity threshold. Focusing on the case of manufacturing firms, Almeida's estimates of the foreign firm wage premium are found to fall from 0.16 in the OLS cross-section estimator (a similar value to the $11 \%$ premium we estimate using worker-levels regressions) to an insignificant coefficient of 0.02 in the difference-in-differences results. As with Conyon et al (2002), important observational differences between acquired and always-domestic firms are also documented, even before acquisition.

Our contribution to this literature is twofold. Firstly, we take the analysis to worker-level data, in order to minimise the aggregation bias implicit in firm-level information. Secondly, we focus on the same workers before and after acquisition (stayers). This should substantially decrease the

\footnotetext{
${ }^{17}$ Other recent papers include Girma and Görg (2003) for the UK and Lipsey and Sjoholm (2003) for Indonesia, both drawing on firm-level data. Both papers document higher wage growth for acquired firms, although the first finds that this result applies only to some industries and when the acquirers are of specific nationalities.

${ }^{18}$ Similar results are obtained when the acquisition dummy is instrumented. However, it is not clear whether the instruments used in the paper pass the validity tests, i.e. whether they can be excluded from the main equation and whether they contribute to the explanatory power of the auxiliary regression.
} 
scope of unobserved heterogeneity to bias our estimates of the foreign ownership effect. Moreover, this approach also means that we do not suffer from the biases that may occur when, upon acquisition, firms adjust their workforces, particularly when such changes occur along unobserved dimensions. For instance, the wage increase documented in Conyon et al (2002) could arise if the foreign owners replace some incumbents prior to acquisition with more skilled individuals.

We construct the data set used in this subsection as follows. The control group includes all firms which are never foreign owned over the up to nine years in which such firms are available in our sample. Only two specific years are considered for the wage analysis: the "before" year is randomly selected in the 1991-1998 range, while the "after" year is the subsequent year available in the sample for that firm. (This is not necessarily the "before" year plus one as the panel is unbalanced.) A total of 23,991 firms (and about 250,000 workers) were found with this method.

The treatment group (domestic firms acquired by foreign parties) was defined as the set of firms whose ownership is initially domestic (i.e. share of equity owned by foreign parties below 50\%) and which in some subsequent year become foreign-owned. Firms following this criterion but in which the foreign acquisition process is reversed at a later stage were dropped. A total of 231 firms (and about 18,000 workers) were found.

These two groups of firms and workers were found to be very different, as far as their observable characteristics are concerned - see Table 8. The treatment workers are more educated than their control group counterparts. The former are also over-represented in bigger firms and in the metallic industry while they are under-represented in the clothing industry, for instance. The distribution of acquisitions per year, in terms of workers, is also less balanced as in the control group, particularly in 1992 (25\% vs 12\%) and in 1995 (6\% vs 13\%). Importantly, there is also a substantial difference in wage growth for each group of workers: the treatment group has an average wage growth of $0.6 \%$ whereas for the control group that figure is $5.1 \%$.

These differences in wage growth may however be due to the different characteristics of each type of workers, not to the acquisition effect. The impact of the treatment was therefore obtained 
from running a regression in which the dependent variable is wage growth between the "before" and "after" period, i.e. differences of the log hourly wage, as in the equation below:

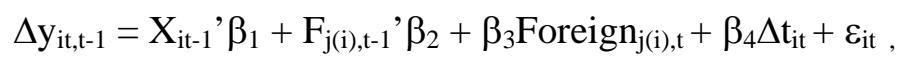

The regressors are the characteristics of the workers and their firms in the "before" period (t-1) and on a dummy variable (Foreign) taking value one for workers in firms that become foreignowned and value zero for workers in firms that are still domestically-owned in the second period. A control for the difference in years between the two periods $\left(\Delta t_{i t}\right)$ is also included.

Consistently with the descriptive statistics, the regression results indicate that, after controlling for the differences in worker characteristics, the impact of foreign acquisition on wages is significantly negative, at -3.1 p.p.. ${ }^{19}$ This negative result is apparently due to the fact that the domestic firms that are subject to an acquisition are paying wages (conditional of firm and worker characteristics) much above the market rates, with respect to their domestic counterparts that will not be subject to an acquisition. Taking the latter group as the benchmark, pooled crosssection OLS results (not reported) find that the domestic firms that will be acquired are paying $11.7 \%$ more. After acquisition, the acquired firms are paying a $7.1 \%$ premium while those firms that remain domestically owned are paying only $0.8 \%$ more.

As a further check on the robustness of these results, we considered a different control group: those firms that are always foreign-owned. The motivation for this choice is that the latter firms (and their workers) are, from the observable point of view, more similar to the treatment group under study. To that extent they stand as a better control group. It turns out, however, that wage growth is still lower for acquired firms than for always-foreign-owned firms, controlling or not for worker and firm characteristics. From the regression results - see Table 8 -, the coefficient on the treatment dummy is -0.042 (-4.1p.p.).

For the benefit of robustness, a further treatment group was considered: the subset of firms in the former target group that exhibit a positive level of foreign ownership before acquisition. The motivation was to control further for the possible selectivity involved in the process of foreign 
acquisition. To the extent that this subset of firms has already been targeted by foreign firms, we may be more likely to pick up with our difference-in-differences estimator only the acquisition effect, rather than a combination between the selection and the acquisition effects. However, we found only 26 firms (and 2,578 workers) that satisfy this condition. These firms (and their workers) also exhibited characteristics which are even more different, with respect to the control group, than our main treatment group (see below). This prompted us to abandon this analysis.

Coming back to the main results of this sub-section, one must describe the findings of negative wage premia as surprising, given the opposite stylised fact in the literature. However, this result is not unexpected from the point of view of the literature on takeovers. Here, it has been hypothesised that a key motivation for the acquisition of firms is that it enables new employers to renege on implicit contracts and to appropriate a larger portion of the surplus produced by employees (Schleifer and Summers, 1988). Other authors claim that mergers and acquisitions stem from a process of improved matches between firms and managers, whereby firms that are being badly run (for instance by paying wages too high given the workers alternative options) are more likely to be taken over (Lichtenberg and Siegel, 1990).

Two other matters should be taken into account. The first is that one may not extrapolate from the wage impact of foreign acquisitions to the wage differences between "standard" multinationals and domestic firms. Possibly a better control group would be domestic firms acquired by different domestic owners but it is not possible to identify these firms given the variables available in this data set. This criticism is, however, attenuated by the stylised fact that most of the current levels of FDI in developing countries (although lower shares in developed countries) are derived from firm acquisitions and not greenfield investment - so, to a large extent, a "standard" foreign firm was in an earlier stage domestically owned. In the specific case of Portugal, over the period 1996-2001, acquisitions (and equity increases) took 39\% of net inward FDI, while greenfield investment (establishment of new firms) represented only $2 \%$ of that total value (Ministério das Finanças, 2003, p. 17). ${ }^{20}$

\footnotetext{
${ }^{19}$ Similar results were obtained when one disregards the panel nature of the data (i.e. if one runs a pooled crosssection regression and focuses on the interaction between the before/after and the foreign dummies). This suggests that, given the controls used, there are not significant unobservable differences across workers.

${ }^{20}$ The remaining share concerns credits and reinvested profits.
} 
Another concern, probably more important, is that "cherry picking" may affect the comparison between acquired and non-acquired domestic firms. This is examined in the next section.

\subsection{Acquisitions - difference-in-differences and propensity score matching}

In this section, we combine the methods of the two previous sections. As mentioned before, this is motivated, inter alia, by the findings of Heckman et al (1997) that a difference-in-differences extension of the method of matching is particularly effective in eliminating bias, especially that due to time-invariant unobserved variables. In this case, that of domestic firms acquired by multinationals, there may be an important dimension of “cherry picking” over both observed and unobserved variables. However, the direction of the bias is unclear, as some authors argue that the asymmetry of information inherent in the acquisition of firms may be particularly acute for foreign firms, leading them to pick "lemons” rather than “cherries” (see Gioia and Thomsen, 2003).

To the extent that the unobserved variables are time-invariant, the combined method used here will provide unbiased estimates of the impact of foreign ownership upon wages. To the more likely extent that some of those variables are not time-invariant but are picked up by the observable variables used here, our approach will reduce the amount of bias. (See Blundell et al, 2004, for an application of this approach to the evaluation of a job search assistance programme.)

In this subsection, we consider as before the same two control groups (always-domestic and always-foreign firms) and the same treatment group (domestic firms that become foreignowned). We find again negative estimates (see the bottom row of Table 8): -1.5 p.p. and -7.8 p.p. for the always domestic and the always foreign control groups, respectively. These results reinforce our previous findings as they suggest that the evidence of lower wage growth documented in the simple difference-in-differences analysis is not due to a poor match between workers in the treatment and control groups.

\section{Conclusions}


We provide new evidence on the role of FDI in labour markets from the perspective of wages, using detailed Portuguese matched data and drawing on a variety of methods. In contrast with the literature, we conclude that the wage differentials between workers in foreign and domestic firms cannot be easily reconciled with a causal impact from ownership to pay.

Although when using OLS methods we find that foreign firms pay more in unconditional terms - the average premium across the nine years covered is about $32 \%$-, the addition of control variables (worker and, in particular, firm characteristics) substantially decreases the premium to an average of about $11 \%$. There was some mild support for a rent-sharing mechanism, as the foreign premium was found to be larger in some industries that may be associated with higher rents. However, no evidence is found of a positive relationship between the degree of foreign control and the wage premium of the firm, unlike what would be expected should foreign control have a positive causal impact upon pay.

We also investigate if the foreign premium is constant along the wage distribution. We find that the premium is generally larger for workers at the top of the conditional distributions. This finding of heterogeneity is consistent with the case in which foreign firms select workers that are more skilled in their unobservable characteristics. Moreover, further evidence at odds with a significant wage premium was obtained using Propensity Score Matching, allowing for better like-for-like comparisons. Using this approach, we find a foreign wage premium on average of $-1 \%$, ranging between $-9 \%$ and $1 \%$, and, in most cases, statistically insignificant.

Finally, we examine the wage consequences of the acquisition of domestic firms by foreign firms, in a difference-in-differences framework, considering two alternative control groups. Consistently with the previous results, negative coefficients are obtained. This finding also holds when we combine difference-in-differences with Propensity Score Matching.

Overall, our results suggest that the foreign-firm wage premium commonly documented in the literature is exaggerated due to a combination of two factors: the lack of a proper like-for-like comparison between domestic and foreign firms; and (to a smaller extent) workers' unobserved heterogeneity. Moreover, our results were obtained for a country with a predominantly noncompetitive labour market, where one could expect wage differentials to be longer lasting. This 
feature reinforces the conclusion that our evidence is at odds with causal interpretations of the foreign-firm wage premium.

These findings may have important implications for public policy. For instance, the results suggest that, should governments want to attract high-wage firms, criteria focusing on firm size or industry are more important than the distinction between domestic and foreign firms. In other words, workers would benefit from the presence of more firms with the characteristics of multinationals, regardless of their nationality. Taken together with the recent but increasingly more abundant evidence of weak productivity spillover effects, our findings strengthen the case for policy makers to re-think their strategies as to the attraction of foreign direct investment.

\section{References}

Aitken, B., Harrison, A, and Lipsey, R. (1996) "Wages and Foreign Ownership. A Comparative Study of Mexico, Venezuela, and the United States”, Journal of International Economics, 40, 345-371.

Almeida, R. (2003) “The Effects of Foreign Owned Firms on the Labor Market”, IZA Discussion Paper 785.

Barbosa, N. and Louri, H. (2002) "On the Determinants of Multinationals Ownership Preferences: Evidence from Greece and Portugal”, International Journal of Industrial Organization, 20, 493-515.

Blanchard, O. and Portugal, P. (2001) "What Hides Behind an Unemployment Rate: Comparing Portuguese and U.S. Labor Markets”, American Economic Review, 91, 187-207.

Blundell, R., Costa Dias, M., Meghir, C. and Van Reenen, J. (2004) "Evaluating the Employment Impact of a Mandatory Job Search Assistance Program”, Journal of the European Economic Association, 2, 569-606. 
Brown, C. and Medoff, J. (1989) “The Employer Size-Wage Effect”, Journal of Political Economy, 97, 1027-1059.

Brown, D., Deardoff, A. and Stern, R. (2003) "The Effects of Multinational Production on Wages and Working Conditions in Developing Countries”, National Bureau of Economic Research Working Paper 9669.

Caves, R. (1996) Multinational Enterprise and Economic Analysis, $2^{\text {nd }}$ edition, Cambridge University Press: Cambridge.

Conyon, M., Girma, S., Thompson, S. and Wright, P. (2002) “The Productivity and Wage Effects of Foreign Acquisition in the United Kingdom”, Journal of Industrial Economics, 50, 85107.

Dunning, J. (1977) “Trade, Location of Economic Activity and the MNEs”, in B. Ohlin, P. Hesselborn and P. Wijkman (eds), The International Allocation of Economic Activity, Macmillan.

Feenstra, R. and Hanson, G. (1997) "Foreign Direct Investment and Relative Wages: Evidence from Mexico’s Maquiladoras”, Journal of International Economics, 42, 371-393.

Feenstra, R. and Hanson, G. (1999) "Productivity Measurement and the Impact of Trade and Technology on Wages: Estimates For the U.S., 1972-1990”, Quarterly Journal of Economics, 114, 907-940.

Feliciano, Z and Lipsey, R. (1999) "Foreign Ownership and Wages in the United States, 1987 1992”, National Bureau of Economic Research Working Paper 6923.

Fosfuri, A., Motta, M. and Rønde, T. (2001) "Foreign Direct Investments and Spillovers Through Workers' Mobility", Journal of International Economics, 53, 205-222.

Gioia, C. and Thomsen, S. (2003) "International Acquisitions in the Danish Business: Selection and Performance”, Copenhagen Business School, mimeo. 
Girma, S. and Görg, H. (2003) "Evaluating the Causal Effects of Foreign Acquisitions on Domestic Skilled and Unskilled Wages”, IZA Discussion Paper 903.

Görg, H. and Greenaway, D. (2004) "Much Ado About Nothing? Do Domestic Firms Really Benefit from Foreign Direct Investment”, World Bank Research Observer, forthcoming.

Görg, H., Strobl, E. and Walsh, F. (2002) "Why do Foreign-Owned Firms Pay More? The Role of On-the-Job Training”, University of Nottingham, mimeo.

Görg, H. and Strobl, E. (2003) “‘Footloose’ Multinationals?”, Manchester School, 71, 1-19.

Griffith, R. and Simpson, H. (2003) "Characteristics of Foreign-Owned Firms In British Manufacturing”, NBER Working Paper 9573.

Guimarães, P., Figueiredo, O. and Woodward, D. (2000) “Agglomeration and the Location of Foreign Direct Investment in Portugal”, Journal of Urban Economics, 47, 115-135.

Heckman, J. Ichimura, H. and Todd, P. (1997) "Matching as an Econometric Evaluation Estimator: Evidence from Evaluating a Job Training Programme”, Review of Economic Studies, 64, 605-654.

Koenker, R. and Bassett, G. (1978) “Regression Quantiles”, Econometrica, 46, 33-50.

Lichtenberg, F. and Siegel, D. (1990) “The Effect of Ownership Change on the Employment and Wages of Central-Office and Other Personnel”, Journal of Law and Economics, 33, 383-408.

Lipsey, R. and Sjoholm, F. (2001) “Foreign Direct Investment and Wages in Indonesian Manufacturing”, National Bureau of Economic Research Working Paper 8299.

Lipsey, R. and Sjoholm, F. (2003) "Foreign Firms and Indonesian Wages: A Panel Study”, National Bureau of Economic Research Working Paper 9417. 
Markusen, J. and Venables, A. (1997) "The Role of Multinational Firms in the Wage-Gap Debate”, Review of International Economics, 5, 435-451.

Martins, P. (2003a) "Firm Wage Differentials in a Competitive Industry: Some Matched-Panel Evidence”, International Journal of Manpower, 24, 336-346.

Martins, P. (2003b) “Rent Sharing and Foreign Ownership”, University of St Andrews, mimeo.

Martins, P. (2004a) “Industry Wage Dispersion: Evidence from the Wage Distribution”, Economics Letters, 83, 157-163.

Martins, P. (2004b) “The Inter-Industry Wage Structure of US Multinationals”, University of St Andrews, mimeo.

Martins, P. (2004c) “Rent Sharing Before and After the Wage Bill”, Queen Mary, University of London, mimeo.

Mata, J. and Portugal, P. (2002) “The Survival of New Domestic and Foreign Owned Firms”, Strategic Management Journal, 23, 323-343.

Ministério das Finanças (2003) "Portugal no Espaço Europeu: O Investimento Directo Estrangeiro” [“Portugal in the European Area: Foreign Direct Investment”], Departamento de Prospectiva e Planeamento, Ministério das Finanças [Finance Ministry], Lisbon.

Oi, W. and Idson, T. (1999) "Firm Size and Wages", in O. Ashenfelter and D. Card (eds) Handbook of Labor Economics, Elsevier: Amsterdam.

Portugal, P. and Cardoso, A. R. (2003) "Disentangling the Minimum Wage Puzzle: An Analysis of Worker Accessions and Separations”, IZA Discussion Paper 544.

Schleifer, A. and Summers, L. (1988) “Breach of Trust in Hostile Take-Overs”, in A. Auerbach (ed) Corporate Take-Overs: Causes and Consequences, NBER: Chicago. 
Sutherland, J. (2002) "The Experience of Work. Is Working for an Overseas-Owned Multinational So Different?”, Employee Relations, 25, 149-167.

Velde, D. and Morrissey, O. (2003) "Do Workers in Africa Get a Wage Premium if Employed in Firms Owned by Foreigners?”, Journal of African Economies, 12, 41-73. 
Table 1a - Descriptive Statistics, Workers in Foreign and Domestic Firms, 1991-1999

\begin{tabular}{|c|c|c|c|c|c|c|c|c|c|c|c|}
\hline & \multirow[b]{2}{*}{ Variable } & \multicolumn{2}{|l|}{1991} & \multicolumn{2}{|l|}{1992} & \multicolumn{2}{|l|}{1993} & \multicolumn{2}{|l|}{1994} & \multicolumn{2}{|l|}{1995} \\
\hline & & Mean & Std. Dev. & Mean & Std. Dev. & Mean & Std. Dev. & Mean & Std. Dev. & Mean & Std. Dev. \\
\hline Foreign & Monthly Earnings & 690.672 & 565.65 & 730.441 & 610.22 & 801.833 & 707.12 & 767.412 & 676.25 & 801.801 & 710.91 \\
\hline \multirow[t]{19}{*}{ Firms } & Hourly Earnings & 4.057 & 4.40 & 4.410 & 10.53 & 4.655 & 4.93 & 4.564 & 4.75 & 4.731 & 5.01 \\
\hline & Log Hourly Earnings & 1.194 & 0.57 & 1.263 & 0.58 & 1.307 & 0.61 & 1.294 & 0.59 & 1.342 & 0.58 \\
\hline & Schooling Years & 6.206 & 3.10 & 6.350 & 3.19 & 6.417 & 3.29 & 6.779 & 3.18 & 6.958 & 3.19 \\
\hline & Experience & 21.713 & 11.77 & 21.628 & 12.05 & 22.450 & 11.66 & 20.537 & 11.43 & 20.725 & 11.31 \\
\hline & Tenure (Months) & 115.027 & 104.89 & 115.957 & 108.70 & 121.226 & 106.47 & 99.074 & 100.01 & 103.560 & 101.68 \\
\hline & Female & 0.561 & & 0.550 & & 0.538 & & 0.576 & & 0.568 & \\
\hline & Food, Beverages & 0.061 & & 0.044 & & 0.068 & & 0.111 & & 0.093 & \\
\hline & Textiles, Clothing, Leather & 0.351 & & 0.331 & & 0.354 & & 0.291 & & 0.268 & \\
\hline & Wood, Cork & 0.013 & & 0.012 & & 0.022 & & 0.016 & & 0.008 & \\
\hline & Paper, Graphical Arts, Edition & 0.038 & & 0.035 & & 0.032 & & 0.022 & & 0.024 & \\
\hline & Chemicals & 0.152 & & 0.157 & & 0.130 & & 0.111 & & 0.082 & \\
\hline & Non-Metalic Minerals & 0.020 & & 0.040 & & 0.035 & & 0.032 & & 0.042 & \\
\hline & Metalurgic & 0.009 & & 0.009 & & 0.007 & & 0.008 & & 0.012 & \\
\hline & Metalic, Transport & 0.347 & & 0.369 & & 0.351 & & 0.407 & & 0.469 & \\
\hline & Others & 0.008 & & 0.003 & & 0.002 & & 0.002 & & 0.002 & \\
\hline & North & 0.447 & & 0.507 & & 0.472 & & 0.350 & & 0.364 & \\
\hline & Centre & 0.100 & & 0.096 & & 0.109 & & 0.241 & & 0.193 & \\
\hline & Lisboa and $\mathrm{T} . \mathrm{V}$. & 0.434 & & 0.390 & & 0.416 & & 0.404 & & 0.438 & \\
\hline & Observations & 52,485 & & 41,671 & & 53,432 & & 57,843 & & 73,795 & \\
\hline & Monthly Earnings & 528.463 & 419.95 & 566.039 & 495.42 & 582.574 & 537.62 & 575.465 & 1322.57 & 562.403 & 477.85 \\
\hline \multirow{19}{*}{ Firms } & Hourly Earnings & 3.118 & 4.12 & 3.309 & 4.50 & 3.399 & 4.42 & 3.438 & 11.71 & 3.342 & 4.30 \\
\hline & Log Hourly Earnings & 0.954 & 0.52 & 1.005 & 0.53 & 1.023 & 0.54 & 1.024 & 0.54 & 1.026 & 0.52 \\
\hline & Schooling Years & 5.260 & 2.67 & 5.353 & 2.71 & 5.481 & 2.76 & 5.735 & 2.78 & 5.758 & 2.74 \\
\hline & Experience & 23.510 & 12.78 & 23.467 & 12.81 & 23.901 & 12.72 & 23.235 & 12.46 & 23.496 & 12.38 \\
\hline & Tenure (Months) & 116.348 & 108.02 & 116.343 & 107.76 & 120.108 & 108.50 & 110.819 & 104.92 & 114.901 & 108.29 \\
\hline & Female & 0.423 & & 0.430 & & 0.417 & & 0.431 & & 0.434 & \\
\hline & Food, Beverages & 0.102 & & 0.105 & & 0.109 & & 0.113 & & 0.107 & \\
\hline & Textiles, Clothing, Leather & 0.401 & & 0.399 & & 0.375 & & 0.384 & & 0.391 & \\
\hline & Wood, Cork & 0.073 & & 0.076 & & 0.080 & & 0.084 & & 0.082 & \\
\hline & Paper, Graphical Arts, Edition & 0.053 & & 0.055 & & 0.060 & & 0.060 & & 0.056 & \\
\hline & Chemicals & 0.070 & & 0.057 & & 0.065 & & 0.063 & & 0.059 & \\
\hline & Non-Metalic Minerals & 0.087 & & 0.080 & & 0.080 & & 0.077 & & 0.083 & \\
\hline & Metalurgic & 0.028 & & 0.025 & & 0.025 & & 0.016 & & 0.016 & \\
\hline & Metalic, Transport & 0.175 & & 0.193 & & 0.197 & & 0.192 & & 0.196 & \\
\hline & Others & 0.010 & & 0.009 & & 0.010 & & 0.010 & & 0.010 & \\
\hline & North & 0.511 & & 0.513 & & 0.499 & & 0.513 & & 0.540 & \\
\hline & Centre & 0.215 & & 0.207 & & 0.224 & & 0.227 & & 0.223 & \\
\hline & Lisboa and $\mathrm{T}$. V. & 0.253 & & 0.257 & & 0.254 & & 0.232 & & 0.211 & \\
\hline & Observations & 471,745 & & 475,336 & & 441,029 & & 404,563 & & 427,461 & \\
\hline
\end{tabular}

Notes:

Monetary values are in real terms (2000 prices) and in euros.

Alentejo and Algarve regional dummies are omitted (their share ranges between .0\% and 3.8\%). 
Table 1b - Descriptive Statistics, Workers in Foreign and Domestic Firms, 1991-1999

\begin{tabular}{|c|c|c|c|c|c|c|c|c|c|c|}
\hline & \multirow[b]{2}{*}{ Variable } & \multicolumn{2}{|l|}{1996} & \multicolumn{2}{|l|}{1997} & \multicolumn{2}{|l|}{1998} & \multicolumn{2}{|l|}{1999} & \multirow{2}{*}{$\begin{array}{c}\text { Annual } \\
\text { Average }\end{array}$} \\
\hline & & Mean & Std. Dev. & Mean & Std. Dev. & Mean & Std. Dev. & Mean & Std. Dev. & \\
\hline Foreign & Monthly Earnings & 806.128 & 763.80 & 841.352 & 721.85 & 841.777 & 713.32 & 863.091 & 756.85 & 793.8 \\
\hline \multirow{19}{*}{ Firms } & Hourly Earnings & 4.728 & 7.80 & 4.837 & 4.42 & 5.001 & 4.58 & 5.147 & 5.56 & 4.7 \\
\hline & Log Hourly Earnings & 1.340 & 0.57 & 1.386 & 0.55 & 1.426 & 0.54 & 1.446 & 0.55 & 1.3 \\
\hline & Schooling Years & 7.196 & 3.31 & 7.255 & 3.32 & 7.221 & 3.27 & 7.367 & 3.36 & 6.9 \\
\hline & Experience & 20.486 & 11.51 & 20.635 & 11.45 & 21.348 & 11.62 & 21.290 & 11.58 & 21.2 \\
\hline & Tenure (Months) & 105.067 & 102.62 & 106.347 & 103.00 & 111.682 & 104.88 & 106.749 & 105.78 & 109.4 \\
\hline & Female & 0.534 & & 0.516 & & 0.548 & & 0.552 & & 0.55 \\
\hline & Food, Beverages & 0.105 & & 0.075 & & 0.077 & & 0.066 & & 0.08 \\
\hline & Textiles, Clothing, Leather & 0.258 & & 0.262 & & 0.267 & & 0.234 & & 0.29 \\
\hline & Wood, Cork & 0.006 & & 0.008 & & 0.016 & & 0.023 & & 0.01 \\
\hline & Paper, Graphical Arts, Edition & 0.021 & & 0.011 & & 0.024 & & 0.024 & & 0.03 \\
\hline & Chemicals & 0.070 & & 0.073 & & 0.116 & & 0.085 & & 0.11 \\
\hline & Non-Metalic Minerals & 0.045 & & 0.036 & & 0.039 & & 0.036 & & 0.04 \\
\hline & Metalurgic & 0.016 & & 0.023 & & 0.018 & & 0.011 & & 0.01 \\
\hline & Metalic, Transport & 0.476 & & 0.510 & & 0.441 & & 0.521 & & 0.43 \\
\hline & Others & 0.002 & & 0.002 & & 0.002 & & 0.001 & & 0.00 \\
\hline & North & 0.360 & & 0.325 & & 0.382 & & 0.398 & & 0.40 \\
\hline & Centre & 0.209 & & 0.229 & & 0.254 & & 0.264 & & 0.19 \\
\hline & Lisboa and T. V. & 0.423 & & 0.434 & & 0.324 & & 0.296 & & 0.40 \\
\hline & Observations & 72,561 & & 74,804 & & 67,971 & & 68,837 & & 62,600 \\
\hline \multirow{20}{*}{ Firms } & Monthly Earnings & 603.105 & 526.74 & 593.721 & 509.92 & 610.191 & 506.39 & 627.803 & 520.11 & 583.3 \\
\hline & Hourly Earnings & 3.519 & 4.96 & 3.536 & 5.00 & 3.708 & 3.78 & 3.854 & 4.13 & 3.5 \\
\hline & Log Hourly Earnings & 1.066 & 0.53 & 1.091 & 0.50 & 1.150 & 0.49 & 1.188 & 0.49 & 1.1 \\
\hline & Schooling Years & 5.922 & 2.87 & 5.958 & 2.84 & 6.124 & 2.95 & 6.206 & 2.98 & 5.8 \\
\hline & Experience & 23.936 & 12.34 & 23.884 & 12.39 & 24.328 & 12.45 & 24.528 & 12.39 & 23.8 \\
\hline & Tenure (Months) & 120.348 & 110.83 & 116.409 & 110.41 & 117.825 & 112.59 & 118.600 & 113.08 & 116.9 \\
\hline & Female & 0.435 & & 0.449 & & 0.436 & & 0.442 & & 0.43 \\
\hline & Food, Beverages & 0.112 & & 0.101 & & 0.106 & & 0.110 & & 0.11 \\
\hline & Textiles, Clothing, Leather & 0.391 & & 0.389 & & 0.363 & & 0.362 & & 0.38 \\
\hline & Wood, Cork & 0.075 & & 0.092 & & 0.089 & & 0.088 & & 0.08 \\
\hline & Paper, Graphical Arts, Edition & 0.061 & & 0.066 & & 0.063 & & 0.062 & & 0.06 \\
\hline & Chemicals & 0.064 & & 0.055 & & 0.062 & & 0.065 & & 0.06 \\
\hline & Non-Metalic Minerals & 0.082 & & 0.082 & & 0.090 & & 0.085 & & 0.08 \\
\hline & Metalurgic & 0.017 & & 0.018 & & 0.016 & & 0.017 & & 0.02 \\
\hline & Metalic, Transport & 0.188 & & 0.186 & & 0.202 & & 0.203 & & 0.19 \\
\hline & Others & 0.010 & & 0.010 & & 0.009 & & 0.008 & & 0.01 \\
\hline & North & 0.537 & & 0.548 & & 0.524 & & 0.533 & & 0.52 \\
\hline & Centre & 0.222 & & 0.225 & & 0.236 & & 0.225 & & 0.22 \\
\hline & Lisboa and T. V. & 0.214 & & 0.201 & & 0.211 & & 0.216 & & 0.23 \\
\hline & Observations & 412,961 & & 428,839 & & 409,721 & & 434,319 & & 433,997 \\
\hline
\end{tabular}

Notes:

Monetary values are in real terms (2000 prices) and in euros.

Alentejo and Algarve regional dummies are omitted (their share ranges between .0\% and 3.8\%) 
Table 2a - Descriptive Statistics, Foreign and Domestic Firms, 1991-1999

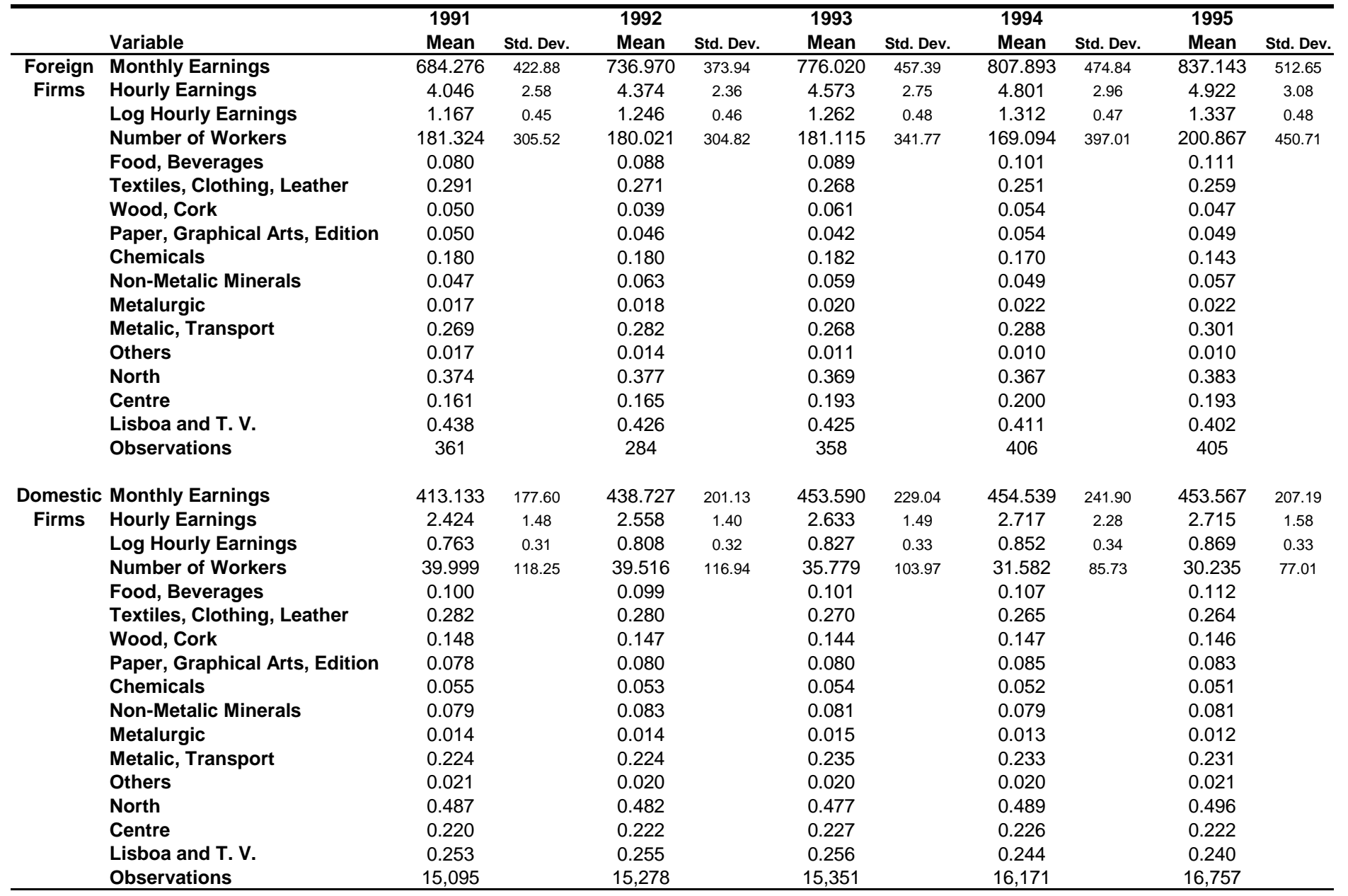

\section{Notes:}

Monetary values are in real terms (2000 prices) and in euros.

Alentejo and Algarve regional dummies are omitted (their share ranges between .0\% and 3.8\%). 
Table 2b - Descriptive Statistics, Foreign and Domestic Firms, 1991-1999

\begin{tabular}{|c|c|c|c|c|c|c|c|c|c|c|}
\hline & & 1996 & & 1997 & & 1998 & & 1999 & & Annual \\
\hline & Variable & Mean & Std. Dev. & Mean & Std. Dev. & Mean & Std. Dev. & Mean & Std. Dev. & Average \\
\hline Foreign & Monthly Earnings & 809.742 & 406.47 & 831.480 & 410.10 & 874.334 & 446.85 & 888.790 & 481.54 & 805.2 \\
\hline Firms & Hourly Earnings & 4.745 & 2.55 & 4.863 & 2.38 & 5.203 & 2.66 & 5.428 & 3.07 & 4.8 \\
\hline & Log Hourly Earnings & 1.319 & 0.45 & 1.364 & 0.43 & 1.437 & 0.44 & 1.466 & 0.44 & 1.3 \\
\hline & Number of Workers & 200.333 & 487.64 & 201.334 & 556.08 & 196.372 & 461.98 & 195.316 & 456.67 & 189.5 \\
\hline & Food, Beverages & 0.119 & & 0.104 & & 0.112 & & 0.093 & & 0.10 \\
\hline & Textiles, Clothing, Leather & 0.258 & & 0.255 & & 0.242 & & 0.225 & & 0.26 \\
\hline & Wood, Cork & 0.028 & & 0.045 & & 0.045 & & 0.061 & & 0.05 \\
\hline & Paper, Graphical Arts, Edition & 0.051 & & 0.037 & & 0.045 & & 0.037 & & 0.05 \\
\hline & Chemicals & 0.157 & & 0.139 & & 0.162 & & 0.154 & & 0.16 \\
\hline & Non-Metalic Minerals & 0.063 & & 0.064 & & 0.061 & & 0.054 & & 0.06 \\
\hline & Metalurgic & 0.018 & & 0.025 & & 0.021 & & 0.017 & & 0.02 \\
\hline & Metalic, Transport & 0.298 & & 0.322 & & 0.303 & & 0.346 & & 0.30 \\
\hline & Others & 0.010 & & 0.010 & & 0.008 & & 0.012 & & 0.01 \\
\hline & North & 0.389 & & 0.356 & & 0.364 & & 0.380 & & 0.37 \\
\hline & Centre & 0.192 & & 0.230 & & 0.237 & & 0.228 & & 0.20 \\
\hline & Lisboa and T. V. & 0.391 & & 0.381 & & 0.370 & & 0.353 & & 0.40 \\
\hline & Observations & 396 & & 404 & & 376 & & 408 & & 378 \\
\hline Domestic & Monthly Earnings & 476.766 & 234.64 & 479.462 & 226.46 & 493.402 & 221.24 & 502.278 & 221.16 & 462.8 \\
\hline Firms & Hourly Earnings & 2.814 & 1.66 & 2.881 & 1.77 & 3.031 & 1.41 & 3.138 & 2.45 & 2.8 \\
\hline & Log Hourly Earnings & 0.898 & 0.33 & 0.934 & 0.32 & 1.004 & 0.30 & 1.039 & 0.30 & 0.9 \\
\hline & Number of Workers & 30.397 & 84.98 & 28.035 & 70.78 & 27.200 & 69.77 & 27.582 & 82.47 & 32.3 \\
\hline & Food, Beverages & 0.114 & & 0.116 & & 0.118 & & 0.114 & & 0.11 \\
\hline & Textiles, Clothing, Leather & 0.263 & & 0.260 & & 0.247 & & 0.251 & & 0.26 \\
\hline & Wood, Cork & 0.139 & & 0.151 & & 0.149 & & 0.152 & & 0.15 \\
\hline & Paper, Graphical Arts, Edition & 0.085 & & 0.083 & & 0.087 & & 0.084 & & 0.08 \\
\hline & Chemicals & 0.051 & & 0.048 & & 0.048 & & 0.048 & & 0.05 \\
\hline & Non-Metalic Minerals & 0.084 & & 0.081 & & 0.086 & & 0.084 & & 0.08 \\
\hline & Metalurgic & 0.011 & & 0.013 & & 0.011 & & 0.013 & & 0.01 \\
\hline & Metalic, Transport & 0.232 & & 0.229 & & 0.236 & & 0.234 & & 0.23 \\
\hline & Others & 0.020 & & 0.019 & & 0.019 & & 0.019 & & 0.02 \\
\hline & North & 0.484 & & 0.497 & & 0.478 & & 0.497 & & 0.49 \\
\hline & Centre & 0.236 & & 0.231 & & 0.240 & & 0.231 & & 0.23 \\
\hline & Lisboa and T. V. & 0.237 & & 0.226 & & 0.233 & & 0.227 & & 0.24 \\
\hline & Observations & 16,093 & & 17,853 & & 17,596 & & 18,819 & & 16,557 \\
\hline
\end{tabular}

\section{Notes:}

Monetary values are in real terms (2000 prices) and in euros.

Alentejo and Algarve regional dummies are omitted (their share ranges between .0\% and 3.8\%). 
Table 3 - Wage Premia of Foreign Firms, 1991-1999.

\begin{tabular}{|c|c|c|c|c|c|c|c|c|c|c|c|c|}
\hline Specifications - Controls & 1991 & 1992 & 1993 & 1994 & 1995 & 1996 & 1997 & 1998 & 1999 & Avg. & Max. & Min. \\
\hline No Controls & $27.1 \%$ & $29.4 \%$ & $32.8 \%$ & $31.0 \%$ & $37.2 \%$ & $31.5 \%$ & $34.3 \%$ & $31.8 \%$ & $29.4 \%$ & $31.6 \%$ & $37.2 \%$ & $27.1 \%$ \\
\hline St. Errors & {$[0.002]^{\star *}$} & {$[0.003]^{\star \star}$} & {$[0.003]^{\star *}$} & {$[0.002]^{\star \star}$} & {$[0.002]^{\star \star}$} & {$[0.002]^{\star \star}$} & {$[0.002]^{\star *}$} & {$[0.002]^{\star \star}$} & {$[0.002]^{\star \star}$} & & & \\
\hline Adjusted R-squared & 0.019 & 0.017 & 0.025 & 0.026 & 0.043 & 0.032 & 0.041 & 0.036 & 0.031 & & & \\
\hline Human Capital (HC) & $23.1 \%$ & $24.5 \%$ & $26.6 \%$ & $28.4 \%$ & $32.3 \%$ & $26.5 \%$ & $26.9 \%$ & $27.9 \%$ & $25.7 \%$ & $26.9 \%$ & $32.3 \%$ & $23.1 \%$ \\
\hline St. Errors & {$[0.002]^{\star \star}$} & {$[0.002]^{\star \star}$} & {$[0.002]^{\star \star}$} & {$[0.002]^{\star \star}$} & {$[0.002]^{\star *}$} & {$[0.002]^{\star \star}$} & {$[0.002]^{\star \star}$} & {$[0.002]^{\star \star}$} & {$[0.002]^{\star \star}$} & & & \\
\hline Adjusted R-squared & 0.451 & 0.436 & 0.45 & 0.438 & 0.453 & 0.453 & 0.445 & 0.477 & 0.477 & & & \\
\hline HC and Firm Characteristics & $11.6 \%$ & $9.6 \%$ & $11.3 \%$ & $10.5 \%$ & $12.2 \%$ & $9.0 \%$ & $8.0 \%$ & $12.6 \%$ & $13.0 \%$ & $10.9 \%$ & $13.0 \%$ & $8.0 \%$ \\
\hline St. Errors & {$[0.002]^{\star *}$} & {$[0.002]^{\star \star}$} & {$[0.002]^{\star *}$} & {$[0.002]^{\star \star}$} & {$[0.002]^{\star *}$} & {$[0.002]^{\star *}$} & {$[0.002]^{\star *}$} & {$[0.002]^{\star *}$} & {$[0.002]^{\star \star}$} & & & \\
\hline Adjusted R-squared & 0.544 & 0.536 & 0.542 & 0.524 & 0.534 & 0.534 & 0.516 & 0.549 & 0.546 & & & \\
\hline Observations & 524,230 & 517,007 & 494,461 & 462,406 & 501,256 & 485,522 & 503,643 & 477,692 & 503,156 & & & \\
\hline
\end{tabular}

Notes:

Standard errors in brackets (* significant at 5\%; ** significant at 1\%).

Human Capital controls are: six dummies for educational degrees, a quartic in experience, a quadratic in tenure (in months), and a female dummy.

Firm Characteristics are: four regional dummies, log number of workers, a dummy for public firms and eight industry dummies. 
Table 4 - Wage Premia of Foreign Firms in Different Industries, 1991-1999.

\begin{tabular}{|c|c|c|c|c|c|c|c|c|c|c|c|c|}
\hline Specifications & 1991 & 1992 & 1993 & 1994 & 1995 & 1996 & 1997 & 1998 & 1999 & Avg. & Max. & Min. \\
\hline Food, Beverages & $\begin{array}{c}6.5 \% \\
{[0.002]^{\star *}}\end{array}$ & $\begin{array}{c}8.4 \% \\
{[0.002]^{\star \star}}\end{array}$ & $\begin{array}{c}9.2 \% \\
{[0.002]^{\star \star}}\end{array}$ & $\begin{array}{c}10.1 \% \\
{[0.002]^{\star *}}\end{array}$ & $\begin{array}{c}10.1 \% \\
{[0.002]^{\star *}}\end{array}$ & $\begin{array}{c}9.7 \% \\
{[0.002]^{\star *}}\end{array}$ & $\begin{array}{c}6.9 \% \\
{[0.002]^{\star *}}\end{array}$ & $\begin{array}{c}9.7 \% \\
{[0.002]^{* *}}\end{array}$ & $\begin{array}{c}8.5 \% \\
{[0.002]^{\star *}}\end{array}$ & $8.8 \%$ & $10.1 \%$ & $6.5 \%$ \\
\hline Wood, Cork & $\begin{array}{c}-2.7 \% \\
{[0.002]^{\star \star}}\end{array}$ & $\begin{array}{l}-0.6 \% \\
{[0.002]^{\star}}\end{array}$ & $\begin{array}{c}-2.2 \% \\
{[0.002]^{\star \star}}\end{array}$ & $\begin{array}{c}1.4 \% \\
{[0.002]^{\star *}}\end{array}$ & $\begin{array}{c}2.6 \% \\
{[0.002]^{\star \star}}\end{array}$ & $\begin{array}{c}4.8 \% \\
{[0.002]^{\star *}}\end{array}$ & $\begin{array}{c}1.7 \% \\
{[0.002]^{* *}}\end{array}$ & $\begin{array}{c}2.3 \% \\
{[0.002]^{* *}}\end{array}$ & $\begin{array}{c}1.5 \% \\
{[0.002]^{\star \star}}\end{array}$ & $1.0 \%$ & $4.8 \%$ & $-2.7 \%$ \\
\hline Paper, Graphical Arts & $\begin{array}{c}28.7 \% \\
{[0.003]^{\star \star}}\end{array}$ & $\begin{array}{c}21.0 \% \\
{[0.003]^{\star \star}}\end{array}$ & $\begin{array}{c}24.4 \% \\
{[0.003]^{\star \star}}\end{array}$ & $\begin{array}{c}26.5 \% \\
{[0.003]^{\star \star}}\end{array}$ & $\begin{array}{c}29.8 \% \\
{[0.003]^{\star \star}}\end{array}$ & $\begin{array}{c}29.8 \% \\
{[0.003]^{\star \star}}\end{array}$ & $\begin{array}{l}25.7 \% \\
{[0.003]^{\star \star}}\end{array}$ & $\begin{array}{l}23.7 \% \\
{[0.002]^{\star *}}\end{array}$ & $\begin{array}{l}25.2 \% \\
{[0.002]^{\star *}}\end{array}$ & $26.1 \%$ & $29.8 \%$ & $21.0 \%$ \\
\hline Chemicals & $\begin{array}{c}29.0 \% \\
{[0.002]^{\star \star}}\end{array}$ & $\begin{array}{c}26.7 \% \\
{[0.003]^{\star \star}}\end{array}$ & $\begin{array}{c}29.7 \% \\
{[0.003]^{\star \star}}\end{array}$ & $\begin{array}{c}28.0 \% \\
{[0.003]^{\star \star}}\end{array}$ & $\begin{array}{c}28.9 \% \\
{[0.003]^{\star \star}}\end{array}$ & $\begin{array}{c}27.4 \% \\
{[0.003]^{\star \star}}\end{array}$ & $\begin{array}{l}23.1 \% \\
{[0.003]^{\star \star}}\end{array}$ & $\begin{array}{c}26.1 \% \\
{[0.002]^{\star *}}\end{array}$ & $\begin{array}{l}24.5 \% \\
{[0.002]^{\star *}}\end{array}$ & $27.1 \%$ & $29.7 \%$ & $23.1 \%$ \\
\hline Non-Metalic Minerals & $\begin{array}{c}19.8 \% \\
{[0.002]^{\star \star}}\end{array}$ & $\begin{array}{c}26.4 \% \\
{[0.002]^{\star \star}}\end{array}$ & $\begin{array}{l}22.5 \% \\
{[0.002]^{\star \star}}\end{array}$ & $\begin{array}{c}23.9 \% \\
{[0.003]^{\star \star}}\end{array}$ & $\begin{array}{c}26.5 \% \\
{[0.002]^{\star \star}}\end{array}$ & $\begin{array}{l}29.6 \% \\
{[0.002]^{\star *}}\end{array}$ & $\begin{array}{c}20.4 \% \\
{[0.002]^{\star *}}\end{array}$ & $\begin{array}{c}20.1 \% \\
{[0.002]^{\star *}}\end{array}$ & $\begin{array}{c}19.8 \% \\
{[0.002]^{\star *}}\end{array}$ & $23.2 \%$ & $29.6 \%$ & $19.8 \%$ \\
\hline Metalurgic & $\begin{array}{c}3.5 \% \\
{[0.003]^{\star \star}}\end{array}$ & $\begin{array}{c}14.7 \% \\
{[0.004]^{\star \star}}\end{array}$ & $\begin{array}{c}13.0 \% \\
{[0.004]^{\star \star}}\end{array}$ & $\begin{array}{c}22.9 \% \\
{[0.005]^{\star \star}}\end{array}$ & $\begin{array}{c}23.5 \% \\
{[0.005]^{\star \star}}\end{array}$ & $\begin{array}{l}29.3 \% \\
{[0.005]^{\star *}}\end{array}$ & $\begin{array}{c}19.0 \% \\
{[0.004]^{\star *}}\end{array}$ & $\begin{array}{c}22.9 \% \\
{[0.004]^{\star *}}\end{array}$ & $\begin{array}{l}22.9 \% \\
{[0.004]^{\star *}}\end{array}$ & $19.1 \%$ & $29.3 \%$ & $3.5 \%$ \\
\hline Metalic, Transport & $\begin{array}{c}13.1 \% \\
{[0.002]^{\star \star}}\end{array}$ & $\begin{array}{c}15.5 \% \\
{[0.002]^{\star \star}}\end{array}$ & $\begin{array}{c}15.7 \% \\
{[0.002]^{\star \star}}\end{array}$ & $\begin{array}{l}21.3 \% \\
{[0.002]^{\star \star}}\end{array}$ & $\begin{array}{l}20.6 \% \\
{[0.002]^{\star \star}}\end{array}$ & $\begin{array}{c}21.8 \% \\
{[0.002]^{\star *}}\end{array}$ & $\begin{array}{c}17.0 \% \\
{[0.002]^{\star *}}\end{array}$ & $\begin{array}{c}15.7 \% \\
{[0.002]^{\star *}}\end{array}$ & $\begin{array}{c}13.8 \% \\
{[0.002]^{\star \star}}\end{array}$ & $17.2 \%$ & $21.8 \%$ & $13.1 \%$ \\
\hline Others & $\begin{array}{c}7.5 \% \\
{[0.005]^{\star \star}}\end{array}$ & $\begin{array}{l}12.1 \% \\
{[0.006]^{\star \star}}\end{array}$ & $\begin{array}{c}10.7 \% \\
{[0.006]^{\star \star}}\end{array}$ & $\begin{array}{c}12.3 \% \\
{[0.006]^{\star \star}}\end{array}$ & $\begin{array}{c}12.6 \% \\
{[0.006]^{\star \star}}\end{array}$ & $\begin{array}{c}10.0 \% \\
{[0.006]^{\star \star}}\end{array}$ & $\begin{array}{c}6.1 \% \\
{[0.006]^{\star *}}\end{array}$ & $\begin{array}{c}6.2 \% \\
{[0.006]^{\star \star}}\end{array}$ & $\begin{array}{c}7.4 \% \\
{[0.006]^{\star \star}}\end{array}$ & $9.4 \%$ & $12.6 \%$ & $6.1 \%$ \\
\hline Foreign Firm & $\begin{array}{c}5.4 \% \\
{[0.003]^{\star \star}}\end{array}$ & $\begin{array}{c}7.8 \% \\
{[0.003]^{\star \star}}\end{array}$ & $\begin{array}{c}4.8 \% \\
{[0.003]^{\star \star}}\end{array}$ & $\begin{array}{c}3.5 \% \\
{[0.003]^{\star \star}}\end{array}$ & $\begin{array}{c}5.9 \% \\
{[0.003]^{\star \star}}\end{array}$ & $\begin{array}{c}3.9 \% \\
{[0.003]^{\star *}}\end{array}$ & $\begin{array}{c}1.9 \% \\
{[0.003]^{\star *}}\end{array}$ & $\begin{array}{c}4.8 \% \\
{[0.003]^{\star *}}\end{array}$ & $\begin{array}{c}3.9 \% \\
{[0.003]^{\star *}}\end{array}$ & $4.6 \%$ & $7.8 \%$ & $1.9 \%$ \\
\hline (Food, Beverages)*For. & $\begin{array}{c}42.5 \% \\
{[0.007]^{\star \star}}\end{array}$ & $\begin{array}{c}11.4 \% \\
{[0.009]^{\star \star}}\end{array}$ & $\begin{array}{c}22.6 \% \\
{[0.007]^{\star \star}}\end{array}$ & $\begin{array}{c}15.0 \% \\
{[0.006]^{\star \star}}\end{array}$ & $\begin{array}{c}22.6 \% \\
{[0.006]^{\star \star}}\end{array}$ & $\begin{array}{l}25.0 \% \\
{[0.005]^{\star \star}}\end{array}$ & $\begin{array}{c}32.3 \% \\
{[0.006]^{\star \star}}\end{array}$ & $\begin{array}{l}28.4 \% \\
{[0.006]^{\star *}}\end{array}$ & $\begin{array}{c}30.3 \% \\
{[0.006]^{\star *}}\end{array}$ & $25.6 \%$ & $42.5 \%$ & $11.4 \%$ \\
\hline (Wood, Cork)^For. & $\begin{array}{c}28.0 \% \\
{[0.014]^{\star \star}}\end{array}$ & $\begin{array}{c}22.5 \% \\
{[0.017]^{\star \star}}\end{array}$ & $\begin{array}{c}7.0 \% \\
{[0.012]^{\star \star}}\end{array}$ & $\begin{array}{c}24.7 \% \\
{[0.013]^{\star \star}}\end{array}$ & $\begin{array}{c}15.0 \% \\
{[0.016]^{\star \star}}\end{array}$ & $\begin{array}{c}18.3 \% \\
{[0.018]^{\star \star}}\end{array}$ & $\begin{array}{l}19.6 \% \\
{[0.015]^{\star \star}}\end{array}$ & $\begin{array}{c}16.5 \% \\
{[0.011]^{\star *}}\end{array}$ & $\begin{array}{l}14.8 \% \\
{[0.009]^{\star *}}\end{array}$ & $18.5 \%$ & $28.0 \%$ & $7.0 \%$ \\
\hline (Paper, Graphical Arts)^For. & $\begin{array}{c}6.9 \% \\
{[0.009]^{\star \star}}\end{array}$ & $\begin{array}{c}14.3 \% \\
{[0.010]^{\star \star}}\end{array}$ & $\begin{array}{c}16.6 \% \\
{[0.010]^{\star \star}}\end{array}$ & $\begin{array}{l}27.4 \% \\
{[0.011]^{\star \star}}\end{array}$ & $\begin{array}{l}29.4 \% \\
{[0.009]^{\star \star}}\end{array}$ & $\begin{array}{c}18.8 \% \\
{[0.010]^{\star *}}\end{array}$ & $\begin{array}{c}8.5 \% \\
{[0.013]^{\star *}}\end{array}$ & $\begin{array}{c}14.7 \% \\
{[0.009]^{\star *}}\end{array}$ & $\begin{array}{l}26.6 \% \\
{[0.009]^{\star *}}\end{array}$ & $18.1 \%$ & $29.4 \%$ & $6.9 \%$ \\
\hline Chemicals*For. & $\begin{array}{l}11.0 \% \\
{[0.005]^{\star \star}}\end{array}$ & $\begin{array}{l}16.5 \% \\
{[0.006]^{\star \star}}\end{array}$ & $\begin{array}{l}18.8 \% \\
{[0.006]^{\star \star}}\end{array}$ & $\begin{array}{c}19.8 \% \\
{[0.006]^{\star \star}}\end{array}$ & $\begin{array}{l}11.2 \% \\
{[0.006]^{\star \star}}\end{array}$ & $\begin{array}{l}17.5 \% \\
{[0.006]^{\star \star}}\end{array}$ & $\begin{array}{l}24.0 \% \\
{[0.006]^{\star *}}\end{array}$ & $\begin{array}{l}16.3 \% \\
{[0.005]^{\star *}}\end{array}$ & $\begin{array}{l}21.9 \% \\
{[0.006]^{\star *}}\end{array}$ & $17.4 \%$ & $24.0 \%$ & $11.0 \%$ \\
\hline 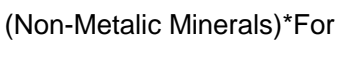 & $\begin{array}{c}8.8 \% \\
{[0.011]^{\star \star}}\end{array}$ & $\begin{array}{c}2.6 \% \\
{[0.010]^{\star \star}}\end{array}$ & $\begin{array}{c}0.0 \% \\
{[0.009]}\end{array}$ & $\begin{array}{c}10.8 \% \\
{[0.010]^{\star \star}}\end{array}$ & $\begin{array}{c}5.4 \% \\
{[0.007]^{\star \star}}\end{array}$ & $\begin{array}{c}8.1 \% \\
{[0.007]^{\star *}}\end{array}$ & $\begin{array}{l}13.8 \% \\
{[0.008]^{\star *}}\end{array}$ & $\begin{array}{c}9.0 \% \\
{[0.007]^{* *}}\end{array}$ & $\begin{array}{l}12.2 \% \\
{[0.008]^{\star \star}}\end{array}$ & $7.9 \%$ & $13.8 \%$ & $0.0 \%$ \\
\hline Metalurgic*For. & $\begin{array}{l}31.5 \% \\
{[0.017]^{\star \star}}\end{array}$ & $\begin{array}{l}-11.6 \% \\
{[0.020]^{\star \star}}\end{array}$ & $\begin{array}{l}13.4 \% \\
{[0.021]^{\star \star}}\end{array}$ & $\begin{array}{l}-2.3 \% \\
{[0.018]}\end{array}$ & $\begin{array}{l}-7.8 \% \\
{[0.013]^{\star \star}}\end{array}$ & $\begin{array}{l}-8.4 \% \\
{[0.012]^{\star \star}}\end{array}$ & $\begin{array}{c}4.0 \% \\
{[0.010]^{\star \star}}\end{array}$ & $\begin{array}{l}-0.9 \% \\
{[0.011]}\end{array}$ & $\begin{array}{l}16.0 \% \\
{[0.013]^{\star \star}}\end{array}$ & $3.8 \%$ & $31.5 \%$ & $-11.6 \%$ \\
\hline (Metalic, Transport)*For. & $\begin{array}{c}1.9 \% \\
{[0.004]^{\star \star}}\end{array}$ & $\begin{array}{c}-5.2 \% \\
{[0.005]^{\star \star}}\end{array}$ & $\begin{array}{c}4.9 \% \\
{[0.004]^{\star \star}}\end{array}$ & $\begin{array}{c}3.9 \% \\
{[0.004]^{\star \star}}\end{array}$ & $\begin{array}{c}4.0 \% \\
{[0.004]^{\star \star}}\end{array}$ & $\begin{array}{l}-0.4 \% \\
{[0.004]}\end{array}$ & $\begin{array}{l}0.2 \% \\
{[0.004]}\end{array}$ & $\begin{array}{c}5.8 \% \\
{[0.004]^{* *}}\end{array}$ & $\begin{array}{c}6.3 \% \\
{[0.004]^{* *}}\end{array}$ & $2.4 \%$ & $6.3 \%$ & $-5.2 \%$ \\
\hline Others*For. & $\begin{array}{l}5.3 \% \\
{[0.019]^{\star *}}\end{array}$ & $\begin{array}{c}-8.2 \% \\
{[0.031]^{\star *}}\end{array}$ & $\begin{array}{l}4.7 \% \\
{[0.033]}\end{array}$ & $\begin{array}{l}5.2 \% \\
{[0.035]}\end{array}$ & $\begin{array}{l}4.7 \% \\
{[0.033]}\end{array}$ & $\begin{array}{l}14.6 \% \\
{[0.034]^{\star *}}\end{array}$ & $\begin{array}{l}9.1 \% \\
{[0.032]^{\star \star}}\end{array}$ & $\begin{array}{l}14.1 \% \\
{[0.028]^{\star *}}\end{array}$ & $\begin{array}{l}14.8 \% \\
{[0.037]^{\star *}}\end{array}$ & $7.1 \%$ & $14.8 \%$ & $-8.2 \%$ \\
\hline $\begin{array}{c}\text { Adjusted R-squared } \\
\text { Observations }\end{array}$ & $\begin{array}{c}0.546 \\
524,230\end{array}$ & $\begin{array}{c}0.538 \\
517,007\end{array}$ & $\begin{array}{c}0.543 \\
494,461\end{array}$ & $\begin{array}{c}0.525 \\
462,406\end{array}$ & $\begin{array}{c}0.536 \\
501,256\end{array}$ & $\begin{array}{c}0.537 \\
485,522\end{array}$ & $\begin{array}{c}0.519 \\
503,643\end{array}$ & $\begin{array}{c}0.551 \\
477,692\end{array}$ & $\begin{array}{c}0.548 \\
503,156\end{array}$ & & & \\
\hline
\end{tabular}

Notes:

Standard errors in brackets ( ${ }^{\star}$ significant at 5\%; ${ }^{\star *}$ significant at $1 \%$ ).

Specification used includes controls for human capital and firm characteristics (see previous tables for definitions). 
Table 5a - Wage Premia of Foreign Firms for Different Degrees of Control, 1991-1999.

\begin{tabular}{|c|c|c|c|c|c|c|c|c|c|c|c|c|}
\hline Specifications & 1991 & 1992 & 1993 & 1994 & 1995 & 1996 & 1997 & 1998 & 1999 & Avg. & Max. & Min. \\
\hline \multirow[t]{2}{*}{$1 \%-9 \%$} & $13.8 \%$ & $9.6 \%$ & $9.5 \%$ & $16.1 \%$ & $13.9 \%$ & $9.7 \%$ & $9.6 \%$ & $2.5 \%$ & $20.7 \%$ & $11.7 \%$ & $20.7 \%$ & $2.5 \%$ \\
\hline & {$[0.006]^{\star *}$} & {$[0.006]^{\star *}$} & {$[0.005]^{\star *}$} & {$[0.006]^{\star \star}$} & {$[0.005]^{\star *}$} & {$[0.006]^{\star *}$} & {$[0.007]^{\star *}$} & {$[0.010]^{*}$} & {$[0.007]^{\star \star}$} & & & \\
\hline \multirow[t]{2}{*}{$10 \%-19 \%$} & $17.2 \%$ & $-2.2 \%$ & $-5.3 \%$ & $22.9 \%$ & $37.2 \%$ & $28.1 \%$ & $25.9 \%$ & $15.6 \%$ & $-3.4 \%$ & $15.1 \%$ & $37.2 \%$ & $-5.3 \%$ \\
\hline & {$[0.008]^{\star *}$} & {$[0.013]$} & {$[0.010]^{\star \star}$} & {$[0.008]^{\star \star}$} & {$[0.007]^{\star \star}$} & {$[0.007]^{\star *}$} & {$[0.008]^{\star \star}$} & {$[0.007]^{\star \star}$} & {$[0.010]^{\star *}$} & & & \\
\hline \multirow[t]{2}{*}{$20 \%-29 \%$} & $18.1 \%$ & $6.4 \%$ & $3.9 \%$ & $4.6 \%$ & $-1.8 \%$ & $14.0 \%$ & $3.6 \%$ & $-4.3 \%$ & $-2.2 \%$ & $4.7 \%$ & $18.1 \%$ & $-4.3 \%$ \\
\hline & {$[0.004]^{\star \star}$} & {$[0.005]^{\star \star}$} & {$[0.006]^{\star \star}$} & {$[0.006]^{\star \star}$} & {$[0.006]^{\star \star}$} & {$[0.006]^{\star \star}$} & {$[0.006]^{\star \star}$} & {$[0.005]^{\star \star}$} & {$[0.006]^{\star \star}$} & & & \\
\hline \multirow[t]{2}{*}{$30 \%-39 \%$} & $19.7 \%$ & $-3.4 \%$ & $-4.1 \%$ & $18.9 \%$ & $12.0 \%$ & $0.0 \%$ & $9.2 \%$ & $11.9 \%$ & $13.9 \%$ & $8.7 \%$ & $19.7 \%$ & $-4.1 \%$ \\
\hline & {$[0.007]^{\star \star}$} & {$[0.008]^{\star \star}$} & {$[0.008]^{\star *}$} & {$[0.008]^{\star \star}$} & {$[0.008]^{\star \star}$} & [0.008] & {$[0.007]^{\star \star}$} & {$[0.007]^{\star \star}$} & {$[0.008]^{\star *}$} & & & \\
\hline \multirow[t]{2}{*}{$40 \%-49 \%$} & $22.5 \%$ & $27.5 \%$ & $19.0 \%$ & $7.9 \%$ & $17.2 \%$ & $11.4 \%$ & $13.7 \%$ & $14.0 \%$ & $15.0 \%$ & $16.5 \%$ & $27.5 \%$ & $7.9 \%$ \\
\hline & {$[0.006]^{\star \star}$} & {$[0.007]^{\star \star}$} & {$[0.007]^{\star *}$} & {$[0.007]^{\star \star}$} & {$[0.007]^{\star \star}$} & {$[0.006]^{\star \star}$} & {$[0.005]^{\star \star}$} & {$[0.006]^{\star \star}$} & {$[0.005]^{\star \star}$} & & & \\
\hline \multirow[t]{2}{*}{$50 \%-59 \%$} & $18.6 \%$ & $6.5 \%$ & $6.6 \%$ & $11.3 \%$ & $8.3 \%$ & $8.5 \%$ & $4.1 \%$ & $-1.2 \%$ & $9.7 \%$ & $8.1 \%$ & $18.6 \%$ & $-1.2 \%$ \\
\hline & {$[0.006]^{\star \star}$} & {$[0.008]^{\star \star}$} & {$[0.006]^{\star \star}$} & {$[0.007]^{\star \star}$} & {$[0.007]^{\star \star}$} & {$[0.007]^{\star \star}$} & {$[0.008]^{\star \star}$} & {$[0.007]$} & {$[0.006]^{\star \star}$} & & & \\
\hline \multirow[t]{2}{*}{$60 \%-69 \%$} & $2.3 \%$ & $17.2 \%$ & $16.6 \%$ & $40.8 \%$ & $36.3 \%$ & $10.4 \%$ & $36.5 \%$ & $36.5 \%$ & $24.6 \%$ & $24.6 \%$ & $40.8 \%$ & $2.3 \%$ \\
\hline & {$[0.010]^{*}$} & {$[0.007]^{\star \star}$} & {$[0.005]^{\star *}$} & {$[0.006]^{\star \star}$} & {$[0.006]^{\star \star}$} & {$[0.008]^{\star \star}$} & {$[0.011]^{\star \star}$} & {$[0.009]^{\star \star}$} & {$[0.009]^{\star \star}$} & & & \\
\hline \multirow[t]{2}{*}{$70 \%-79 \%$} & $2.1 \%$ & $0.5 \%$ & $21.2 \%$ & $38.3 \%$ & $26.9 \%$ & $25.0 \%$ & $6.2 \%$ & $23.6 \%$ & $-5.4 \%$ & $15.4 \%$ & $38.3 \%$ & $-5.4 \%$ \\
\hline & {$[0.009]^{*}$} & [0.011] & {$[0.009]^{\star *}$} & {$[0.010]^{\star *}$} & {$[0.007]^{\star \star}$} & {$[0.008]^{\star \star}$} & {$[0.009]^{\star \star}$} & {$[0.009]^{\star *}$} & {$[0.008]^{\star \star}$} & & & \\
\hline \multirow[t]{2}{*}{$80 \%-89 \%$} & $7.6 \%$ & $10.5 \%$ & $10.5 \%$ & $12.9 \%$ & $12.2 \%$ & $10.5 \%$ & $17.4 \%$ & $14.6 \%$ & $14.3 \%$ & $12.3 \%$ & $17.4 \%$ & $7.6 \%$ \\
\hline & {$[0.005]^{\star *}$} & {$[0.008]^{\star \star}$} & {$[0.010]^{\star \star}$} & {$[0.009]^{\star \star}$} & {$[0.008]^{\star \star}$} & {$[0.008]^{\star *}$} & {$[0.006]^{\star \star}$} & {$[0.006]^{\star \star}$} & {$[0.007]^{\star \star}$} & & & \\
\hline \multirow[t]{2}{*}{$90 \%-99 \%$} & $11.5 \%$ & $8.0 \%$ & $15.6 \%$ & $10.6 \%$ & $10.3 \%$ & $15.5 \%$ & $13.9 \%$ & $10.8 \%$ & $17.7 \%$ & $12.7 \%$ & $17.7 \%$ & $8.0 \%$ \\
\hline & {$[0.004]^{\star \star}$} & {$[0.004]^{\star \star}$} & {$[0.004]^{\star *}$} & {$[0.004]^{\star *}$} & {$[0.003]^{\star \star}$} & {$[0.003]^{\star \star}$} & {$[0.003]^{\star \star}$} & {$[0.003]^{\star \star}$} & {$[0.004]^{\star *}$} & & & \\
\hline \multirow[t]{2}{*}{$100 \%$} & $15.8 \%$ & $11.2 \%$ & $10.4 \%$ & $7.9 \%$ & $12.6 \%$ & $7.8 \%$ & $6.7 \%$ & $13.7 \%$ & $13.3 \%$ & $11.0 \%$ & $15.8 \%$ & $6.7 \%$ \\
\hline & {$[0.002]^{\star \star}$} & {$[0.003]^{\star \star}$} & {$[0.002]^{\star \star}$} & {$[0.002]^{\star \star}$} & {$[0.002]^{\star \star}$} & {$[0.002]^{\star \star}$} & {$[0.002]^{\star \star}$} & {$[0.002]^{\star \star}$} & {$[0.002]^{\star \star}$} & & & \\
\hline Adjusted $\mathrm{R}^{2}$ & 0.548 & 0.538 & 0.543 & 0.528 & 0.538 & 0.537 & 0.518 & 0.551 & 0.548 & & & \\
\hline Observations & 524,230 & 517,007 & 494,461 & 462,406 & 501,256 & 485,522 & 503,643 & 477,692 & 503,156 & & & \\
\hline
\end{tabular}

Notes:

Standard errors in brackets (* significant at 5\%; ** significant at 1\%).

Specification used includes controls for human capital and firm characteristics (see previous tables for definitions). 
Table 5b - Wage Premia for Foreign Firms, Different Definitions, 1991-1999

\begin{tabular}{|c|c|c|c|c|c|c|c|c|c|c|c|c|c|c|c|c|c|c|}
\hline & \multicolumn{2}{|c|}{1991} & \multicolumn{2}{|c|}{1992} & \multicolumn{2}{|c|}{1993} & \multicolumn{2}{|c|}{1994} & \multicolumn{2}{|c|}{1995} & \multicolumn{2}{|c|}{1996} & \multicolumn{2}{|c|}{1997} & \multicolumn{2}{|c|}{1998} & \multicolumn{2}{|c|}{1999} \\
\hline & Premium & St. Error & Premium & St. Error & Premium & St. Error & Premium & St. Error & Premium & St. Error & Premium & St. Error & Premium & St. Error & Premium & St. Error & Premium & St. Error \\
\hline$>=10 \%$ & $14.8 \%$ & $(0.002)^{* *}$ & $9.9 \%$ & $(0.002)^{* *}$ & $10.3 \%$ & $(0.002)^{\star *}$ & $11.3 \%$ & $(0.002)^{\star \star}$ & $13.1 \%$ & $(0.002)^{* *}$ & $10.5 \%$ & $(0.002)^{\star \star}$ & $9.3 \%$ & $(0.002)^{\star \star}$ & $12.3 \%$ & $(0.002)^{\star *}$ & $12.3 \%$ & $(0.001)^{*+*}$ \\
\hline$>=20 \%$ & $14.7 \%$ & $(0.002)^{\star *}$ & $10.1 \%$ & $(0.002)^{\star \star}$ & $10.7 \%$ & $(0.002)^{* *}$ & $10.5 \%$ & $(0.002)^{\star \star}$ & $11.7 \%$ & $(0.002)^{\star \star}$ & $9.4 \%$ & $(0.002)^{* *}$ & $8.4 \%$ & $(0.002)^{\star *}$ & $12.0 \%$ & $(0.002)^{\star *}$ & $12.7 \%$ & $(0.002)^{* *}$ \\
\hline$>=30 \%$ & $13.0 \%$ & $(0.002)^{\star *}$ & $10.2 \%$ & $(0.002)^{\star *}$ & $11.2 \%$ & $(0.002)^{\star \star}$ & $10.8 \%$ & $(0.002)^{\star \star}$ & $12.7 \%$ & $(0.002)^{\star \star}$ & $8.9 \%$ & $(0.002)^{\star \star}$ & $8.7 \%$ & $(0.002)^{\star \star}$ & $13.1 \%$ & $(0.002)^{\star \star}$ & $13.4 \%$ & $(0.002)^{* *}$ \\
\hline$>=40 \%$ & $12.5 \%$ & $(0.002)^{\star *}$ & $11.0 \%$ & $(0.002)^{\star \star}$ & $12.0 \%$ & $(0.002)^{\star *}$ & $10.4 \%$ & $(0.002)^{\star \star *}$ & $12.6 \%$ & $(0.002)^{\star *}$ & $9.2 \%$ & $(0.002)^{\star \star *}$ & $8.5 \%$ & $(0.002)^{\star \star *}$ & $13.0 \%$ & $(0.002)^{\star *}$ & $13.3 \%$ & $(0.002)^{* *}$ \\
\hline$>=50 \%$ & $11.6 \%$ & $(0.002)^{\star *}$ & $9.6 \%$ & $(0.002)^{\star *}$ & $11.3 \%$ & $(0.002)^{* *}$ & $10.5 \%$ & $(0.002)^{\star \star}$ & $12.2 \%$ & $(0.002)^{\star \star}$ & $9.0 \%$ & $(0.002)^{* *}$ & $8.0 \%$ & $(0.002)^{\star *}$ & $12.6 \%$ & $(0.002)^{\star *}$ & $13.0 \%$ & $(0.002)^{*+*}$ \\
\hline N. Obs. & 524230 & & 517007 & & 494461 & & 462406 & & 501256 & & 485522 & & 503643 & & 477692 & & & \\
\hline
\end{tabular}

\section{Notes:}

Standard errors in parentheses: * significant at 5\% level; ** significant at $1 \%$ level

The specification considered includes human capital and firm characteristics. 
Table 6 - Quantile Regression Results

\begin{tabular}{ccccc}
\hline & \multicolumn{2}{c}{ 25th perc. } & \multicolumn{2}{c}{ 75th perc. } \\
& Coeff. & St. Error & Coeff. & Error \\
\hline $\mathbf{1 9 9 1}$ & 0.1027 & 0.0015 & 0.1096 & 0.0019 \\
$\mathbf{1 9 9 2}$ & 0.0953 & 0.0017 & 0.0888 & 0.0026 \\
$\mathbf{1 9 9 3}$ & 0.0944 & 0.0016 & 0.1136 & 0.0028 \\
$\mathbf{1 9 9 4}$ & 0.0848 & 0.0015 & 0.1159 & 0.0020 \\
$\mathbf{1 9 9 5}$ & 0.0951 & 0.0014 & 0.1255 & 0.0018 \\
$\mathbf{1 9 9 6}$ & 0.0704 & 0.0014 & 0.0978 & 0.0019 \\
$\mathbf{1 9 9 7}$ & 0.0683 & 0.0016 & 0.0920 & 0.0024 \\
$\mathbf{1 9 9 8}$ & 0.0969 & 0.0014 & 0.1386 & 0.0022 \\
$\mathbf{1 9 9 9}$ & 0.1085 & 0.0016 & 0.1345 & 0.0024 \\
\hline
\end{tabular}

Note:

In each each, the full set of controls is considered. 
Table 7 - Propensity Score Matching estimates

\begin{tabular}{ccc}
\hline Year & Estimate & St. Error \\
\hline $\mathbf{1 9 9 1}$ & $-2.36 \%$ & 0.006 \\
$\mathbf{1 9 9 2}$ & $0.31 \%$ & 0.007 \\
$\mathbf{1 9 9 3}$ & $1.30 \%$ & 0.006 \\
$\mathbf{1 9 9 4}$ & $-8.93 \%$ & 0.010 \\
$\mathbf{1 9 9 5}$ & $-0.44 \%$ & 0.010 \\
$\mathbf{1 9 9 6}$ & $-1.95 \%$ & 0.013 \\
$\mathbf{1 9 9 7}$ & $-0.14 \%$ & 0.012 \\
$\mathbf{1 9 9 8}$ & $1.09 \%$ & 0.008 \\
$\mathbf{1 9 9 9}$ & $0.17 \%$ & 0.010 \\
Average & $-1.22 \%$ & \\
\hline
\end{tabular}

Note:

Standard errors obtained via bootstrapping (50 repetitions) 
Table 8 - Difference-in-differences Descriptive Statistics and Results

Control group: workers in firms that are always domestically-owned.

\begin{tabular}{|c|c|c|c|c|c|c|c|}
\hline \multirow[b]{2}{*}{ Variable } & \multirow{2}{*}{$\begin{array}{c}\text { Treatment } \\
\text { Mean }\end{array}$} & \multirow{2}{*}{$\begin{array}{c}\text { Control } 1 \\
\text { Mean }\end{array}$} & \multicolumn{2}{|c|}{ DID - Control 1} & \multirow{2}{*}{$\begin{array}{c}\text { Control } 2 \\
\text { Mean }\end{array}$} & \multicolumn{2}{|c|}{ DID - Control 2} \\
\hline & & & Coeff. & St. Error & & Coeff. & St. Error \\
\hline Change in Log Hourly Wages & 0.006 & 0.051 & & & 0.070 & & \\
\hline 1st Cycle & 0.399 & 0.509 & -0.014 & 0.003 & 0.340 & -0.038 & 0.010 \\
\hline 2nd Cycle & 0.232 & 0.263 & -0.009 & 0.003 & 0.307 & -0.027 & 0.010 \\
\hline 3rd Cycle & 0.170 & 0.098 & -0.014 & 0.004 & 0.189 & -0.031 & 0.010 \\
\hline Secondary & 0.107 & 0.063 & -0.009 & 0.004 & 0.108 & -0.019 & 0.011 \\
\hline "Bacharelato" & 0.017 & 0.007 & 0.009 & 0.008 & 0.013 & -0.003 & 0.016 \\
\hline "Licenciatura" & 0.040 & 0.014 & 0.001 & 0.006 & 0.023 & -0.011 & 0.013 \\
\hline Experience & 115.247 & 127.974 & 0.000 & 0.000 & 111.62 & 0.000 & 0.000 \\
\hline Tenure (Months) & 22.570 & 24.350 & -0.001 & 0.000 & 20.80 & -0.003 & 0.000 \\
\hline Female & 0.386 & 0.426 & -0.012 & 0.001 & 0.56 & -0.021 & 0.003 \\
\hline Log Firm Size & 6.080 & 4.766 & -0.008 & 0.000 & 6.38 & -0.030 & 0.001 \\
\hline Difference in Years & 1.410 & 1.332 & 0.030 & 0.001 & 1.53 & 0.074 & 0.002 \\
\hline Food, Beverages & 0.088 & 0.109 & 0.013 & 0.002 & 0.064 & -0.021 & 0.007 \\
\hline Wood, Cork & 0.039 & 0.081 & -0.001 & 0.003 & 0.011 & -0.108 & 0.011 \\
\hline Paper, Graphical Arts, Edition & 0.038 & 0.051 & 0.005 & 0.003 & 0.013 & 0.029 & 0.011 \\
\hline Chemicals & 0.091 & 0.059 & -0.026 & 0.003 & 0.128 & -0.056 & 0.006 \\
\hline Non-Metalic Minerals & 0.032 & 0.082 & 0.015 & 0.003 & 0.033 & -0.044 & 0.009 \\
\hline Metalurgic & 0.017 & 0.015 & 0.015 & 0.005 & 0.007 & -0.188 & 0.011 \\
\hline Metalic, Transport & 0.443 & 0.197 & 0.008 & 0.002 & 0.504 & -0.034 & 0.005 \\
\hline Others & 0.001 & 0.008 & -0.015 & 0.007 & 0.001 & -0.103 & 0.039 \\
\hline Centre & 0.211 & 0.229 & -0.001 & 0.002 & 0.238 & 0.038 & 0.005 \\
\hline Lisboa and T. V. & 0.408 & 0.216 & -0.020 & 0.002 & 0.380 & 0.009 & 0.004 \\
\hline Alentejo & 0.033 & 0.013 & -0.008 & 0.005 & 0.004 & 0.033 & 0.014 \\
\hline Algarve & 0.001 & 0.007 & -0.032 & 0.007 & 0.000 & 0.289 & 0.067 \\
\hline 1991 & 0.165 & 0.148 & 0.008 & 0.003 & 0.104 & -0.125 & 0.006 \\
\hline 1992 & 0.250 & 0.117 & -0.059 & 0.003 & 0.139 & -0.004 & 0.006 \\
\hline 1993 & 0.108 & 0.114 & -0.042 & 0.003 & 0.227 & 0.018 & 0.006 \\
\hline 1994 & 0.089 & 0.118 & -0.024 & 0.003 & 0.211 & 0.000 & 0.006 \\
\hline 1995 & 0.063 & 0.131 & -0.022 & 0.003 & 0.055 & 0.004 & 0.007 \\
\hline 1996 & 0.161 & 0.158 & 0.023 & 0.002 & 0.098 & -0.020 & 0.007 \\
\hline 1997 & 0.069 & 0.116 & 0.001 & 0.003 & 0.068 & 0.002 & 0.007 \\
\hline Treatment & & & -0.031 & 0.003 & & -0.042 & 0.003 \\
\hline Observations & 18,269 & 250,031 & 268,300 & & 27,229 & 46,476 & \\
\hline Adj. $R$ squared & & & 0.0165 & & & 0.0983 & \\
\hline Propensity Score estimate & & & $-1.54 \%$ & & & $-7.83 \%$ & \\
\hline
\end{tabular}

Notes:

Treatment group: Workers in firms that are domestic in the first period and foreign in the second.

Control group 1: firms that are always domestically owned.

Control group 2: firms that are always foreign owned.

The standard deviations of the change in log wages is $0,358,0,31$ and 0,3 for the treatment

group and for the two control groups, respectively. 
Table A1a - Descriptive Statistics, Workers in Foreign and Domestic Firms, 1991-1999 (10\% foreign ownership definition).

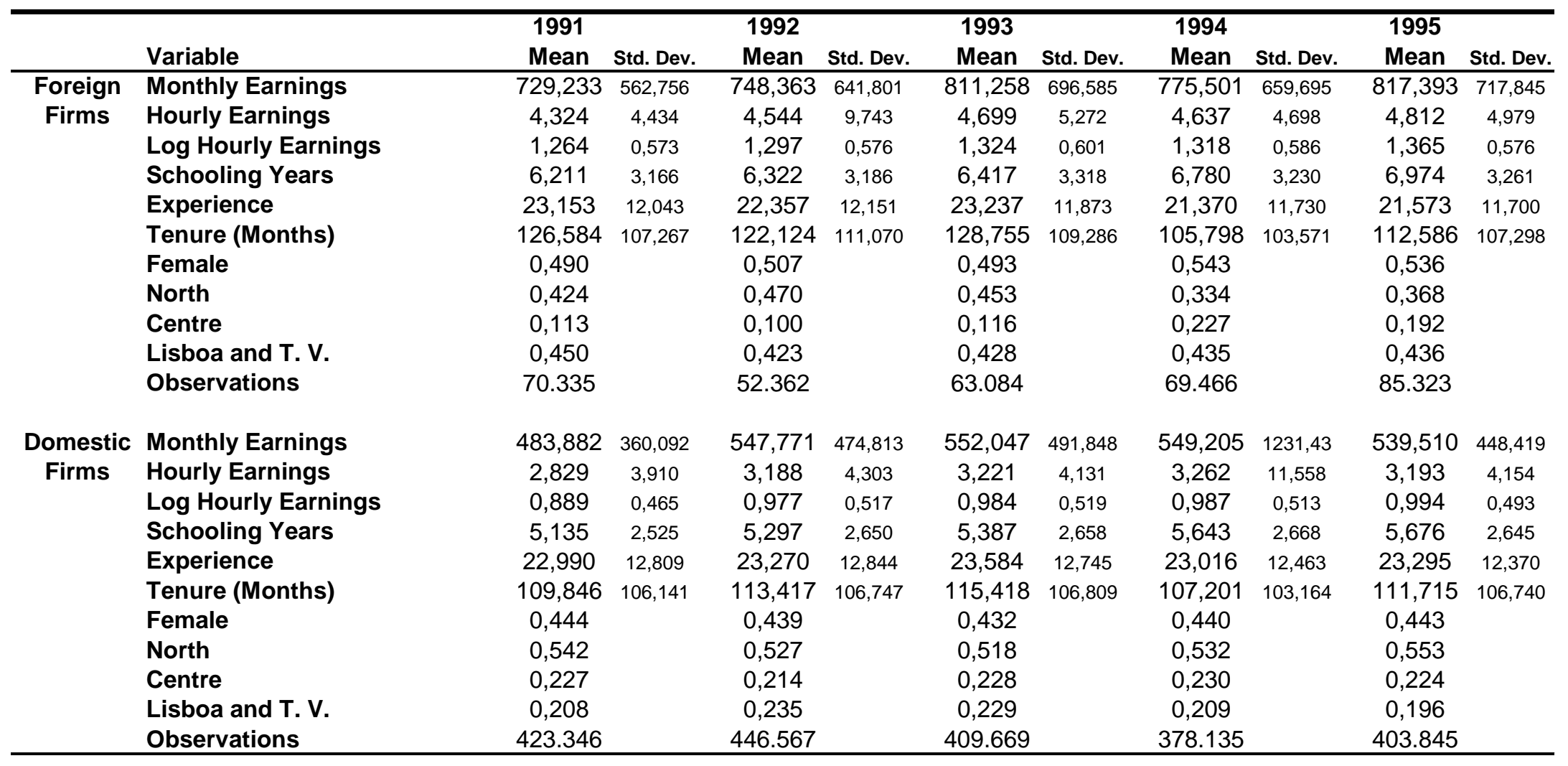

Notes:

Monetary values are in real terms (2000 prices) and in euros.

Alentejo and Algarve regional dummies are omitted (their share ranges between .0\% and 3.8\%). 
Table A1b - Descriptive Statistics, Workers in Foreign and Domestic Firms, 1991-1999 (10\% foreign ownership definition).

\begin{tabular}{|c|c|c|c|c|c|c|c|c|c|c|}
\hline & \multirow[b]{2}{*}{ Variable } & \multicolumn{2}{|l|}{1996} & \multicolumn{2}{|l|}{1997} & \multicolumn{2}{|l|}{1998} & \multicolumn{2}{|l|}{1999} & \multirow{2}{*}{$\begin{array}{l}\text { Annual } \\
\text { Average }\end{array}$} \\
\hline & & Mean & Std. Dev. & Mean & Std. Dev. & Mean & Std. Dev. & Mean & Std. Dev. & \\
\hline Foreign & Monthly Earnings & 832,928 & 767,144 & 860,720 & 720,861 & 855,704 & 725,472 & 875,588 & 748,271 & 811,85 \\
\hline \multirow[t]{10}{*}{ Firms } & Hourly Earnings & 4,877 & 7,502 & 4,955 & 4,485 & 5,088 & 4,644 & 5,267 & 6,442 & 4,80 \\
\hline & Log Hourly Earnings & 1,370 & 0,574 & 1,411 & 0,555 & 1,447 & 0,538 & 1,465 & 0,550 & 1,36 \\
\hline & Schooling Years & 7,180 & 3,355 & 7,267 & 3,375 & 7,255 & 3,332 & 7,369 & 3,406 & 6,86 \\
\hline & Experience & 21,365 & 11,859 & 21,470 & 11,844 & 22,107 & 11,964 & 22,016 & 11,854 & 22,07 \\
\hline & Tenure (Months) & 113,653 & 107,760 & 114,099 & 108,326 & 120,692 & 111,406 & 114,733 & 111,051 & 117,67 \\
\hline & Female & 0,502 & & 0,487 & & 0,512 & & 0,516 & & 0,51 \\
\hline & North & 0,364 & & 0,334 & & 0,389 & & 0,393 & & 0,39 \\
\hline & Centre & 0,206 & & 0,228 & & 0,253 & & 0,256 & & 0,19 \\
\hline & Lisboa and T. V. & 0,423 & & 0,428 & & 0,323 & & 0,314 & & 0,41 \\
\hline & Observations & 84.861 & & 88.031 & & 80.615 & & 79.459 & & 74.837 \\
\hline Domestic & Monthly Earnings & 571,277 & 484,371 & 568,369 & 487,239 & 580,210 & 464,515 & 602,491 & 488,942 & 554,97 \\
\hline \multirow[t]{10}{*}{ Firms } & Hourly Earnings & 3,329 & 4,797 & 3,384 & 4,802 & 3,528 & 3,579 & 3,690 & 3,605 & 3,29 \\
\hline & Log Hourly Earnings & 1,029 & 0,503 & 1,059 & 0,482 & 1,116 & 0,464 & 1,159 & 0,468 & 1,02 \\
\hline & Schooling Years & 5,822 & 2,762 & 5,874 & 2,757 & 6,009 & 2,842 & 6,119 & 2,899 & 5,66 \\
\hline & Experience & 23,761 & 12,348 & 23,675 & 12,369 & 24,203 & 12,446 & 24,365 & 12,376 & 23,57 \\
\hline & Tenure (Months) & 116,938 & 109,310 & 112,610 & 108,318 & 114,152 & 110,524 & 115,158 & 111,048 & 112,94 \\
\hline & Female & 0,445 & & 0,460 & & 0,447 & & 0,453 & & 0,44 \\
\hline & North & 0,554 & & 0,561 & & 0,535 & & 0,548 & & 0,54 \\
\hline & Centre & 0,222 & & 0,224 & & 0,240 & & 0,224 & & 0,23 \\
\hline & Lisboa and T. V. & 0,196 & & 0,187 & & 0,194 & & 0,201 & & 0,21 \\
\hline & Observations & 388.000 & & 402.799 & & 384.213 & & 411.037 & & 404.572 \\
\hline
\end{tabular}

Notes:

Monetary values are in real terms (2000 prices) and in euros.

Alentejo and Algarve regional dummies are omitted (their share ranges between .0\% and 3.8\%). 
Table A2 - Wage Premia of Foreign Firms, 1991-1999 (10\% foreign ownership definition).

\begin{tabular}{|c|c|c|c|c|c|c|c|c|c|c|c|c|}
\hline Specifications - Controls & 1991 & 1992 & 1993 & 1994 & 1995 & 1996 & 1997 & 1998 & 1999 & Avg. & Max. & Min. \\
\hline No Controls & $39,2 \%$ & $35,3 \%$ & $36,2 \%$ & $35,9 \%$ & $42,3 \%$ & $37,6 \%$ & $39,9 \%$ & $36,3 \%$ & $33,4 \%$ & $37,4 \%$ & $42,3 \%$ & $33,4 \%$ \\
\hline St. Errors & {$[0.002]^{\star \star}$} & {$[0.003]^{\star *}$} & {$[0.003]^{\star \star}$} & {$[0.002]^{\star *}$} & {$[0.002]^{\star \star}$} & {$[0.002]^{\star \star}$} & {$[0.002]^{\star *}$} & {$[0.002]^{\star \star}$} & {$[0.002]^{\star \star}$} & & & \\
\hline Adjusted R-squared & 0,046 & 0,029 & 0,035 & 0,039 & 0,061 & 0,049 & 0,06 & 0,053 & 0,044 & & & \\
\hline Human Capital (HC) & $27,4 \%$ & $26,5 \%$ & $25,5 \%$ & $29,2 \%$ & $32,7 \%$ & $28,1 \%$ & $28,1 \%$ & $28,0 \%$ & $25,7 \%$ & $27,9 \%$ & $32,7 \%$ & $25,5 \%$ \\
\hline St. Errors & {$[0.002]^{\star \star}$} & {$[0.002]^{\star \star}$} & {$[0.002]^{\star \star}$} & {$[0.002]^{\star \star}$} & {$[0.002]^{\star \star}$} & {$[0.002]^{\star \star}$} & {$[0.002]^{\star \star}$} & {$[0.002]^{\star \star}$} & {$[0.002]^{\star \star}$} & & & \\
\hline Adjusted R-squared & 0,461 & 0,443 & 0,453 & 0,444 & 0,46 & 0,461 & 0,452 & 0,482 & 0,481 & & & \\
\hline $\mathrm{HC}$ and Firm Characteristics & $15,0 \%$ & $9,7 \%$ & $10,4 \%$ & $11,3 \%$ & $13,0 \%$ & $11,4 \%$ & $9,2 \%$ & $12,6 \%$ & $12,9 \%$ & $11,7 \%$ & $15,0 \%$ & $9,2 \%$ \\
\hline St. Errors & {$[0.002]^{\star \star}$} & {$[0.002]^{\star \star}$} & {$[0.002]^{\star \star}$} & {$[0.002]^{\star \star}$} & {$[0.002]^{\star \star}$} & {$[0.002]^{\star \star}$} & {$[0.002]^{\star \star}$} & {$[0.002]^{\star \star}$} & {$[0.002]^{\star \star}$} & & & \\
\hline Adjusted R-squared & 0,548 & 0,539 & 0,543 & 0,526 & 0,541 & 0,541 & 0,522 & 0,554 & 0,56 & & & \\
\hline Observations & 524.230 & 517.007 & 494.461 & 462.406 & 501.256 & 485.522 & 503.643 & 477.692 & 503.156 & & & \\
\hline
\end{tabular}

Notes:

Standard errors in brackets ( ${ }^{*}$ significant at $5 \%$; ${ }^{*}$ significant at $\left.1 \%\right)$.

Human Capital controls are: six dummies for educational degrees, a quartic in experience, a quadratic in tenure (in months), and a female dummy.

Firm Characteristics are: four regional dummies, log number of workers, a dummy for public firms and eight industry dummies. 